\title{
Bainang Terrane, Yarlung-Tsangpo suture, southern Tibet (Xizang, China): a record of intra-Neotethyan subduction-accretion processes preserved on the roof of the world
}

\author{
SERGEY V. ZIABREV ${ }^{1,2}$, JONATHAN C. AITCHISON', \\ ALEXANDRA V. ABRAJEVITCH ${ }^{1,3}$, BADENGZHU⿱4 , AILEEN M. DAVIS' \& HUI LUO ${ }^{1,5}$ \\ ${ }^{1}$ Tibet Research Group, Department of Earth Sciences, University of Hong Kong, Pokfulam Road, Hong Kong SAR, China \\ (e-mail: jona@hku.hk) \\ ${ }^{2}$ Present address: Institute of Tectonics and Geophysics, Russian Academy of Sciences, Kim-Yu-Chen St., 65, Khabarovsk, \\ 680000 , Russia \\ ${ }^{3}$ Present address: Department of Geological Sciences, University of Michigan, 425 E. University Ave., Ann Arbor; MI \\ 48109-1063, USA \\ ${ }^{4}$ Geological Team No. 2, Tibet Geological Survey, Lhasa, Tibet, China \\ ${ }^{5}$ Present address: Nanjing Institute of Geology and Palaeontology, Laboratory of Palaeobiology and Stratigruphy, \\ Academia Sinica, Nanjing 210008, China
}

\begin{abstract}
The Bainang terrane, an intra-oceanic island arc subduction conplex into which Tethyan oceanic rocks were accreted during the Cretaceous, is preserved within the Yarlung-Tsangpo suture zone of Tibet. The lithostratigraphic succession established from field mapping records a long history of sedimentation in different portions of the central Tethyan domain from Late Triassic to mid-Cretaceous time. These rocks are preserved within a soutl-verging imbricate thrust stack of thin $(\ll 1 \mathrm{~km}$ thick) northward younging tectonic slices. Five lithotectonic units were mapped in the terrane and these units are assigned to two distinct tracts. The northern tract, which accumulated on the north side of Neotethys, was probably separated from its southern counterpart by a mid-ocean ridge. Detailed radiolarian biostratigraphy is used to constrain the timing of depositional events within each tract. Occanic plate stratigraphy of the northem tract records its northward travel and mid-Cretaceous (late Aptian) approach towards a south-facing intra-occanic subduction zone. Rocks: in the southern tract developed closer to the Indian subcontinent and experienced thermotectonic subsidence and Mid-Jurassic basic alkaline intraplate magmatism. They were probably acereted late in the Crelaceous. Variations in structural style across the terrane indicate deformation at different depths and vertical growth of the wedge rather than lateral accretion. The overall tectonostratigraphy of the terrane reflects its development ill a remote intra-oceanic setting.
\end{abstract}

Keywords: Tibet, Mesozoic, accretionary wedges, subduction, accretion, Indus - Yarlung-Zangbo suturc zone, radiolarians.

The Yarlung-Tsangpo suture zone in Tibet marks the zone of collision between India and Eurasia. The once vast Tethyan Occan closed along this suture during Cenozoic continentcontinent collision. Much of what lay within this ocean was subducted, smeared out or otherwise destroyed through subduction during convergence between India and Asia or disappeared during the collision. All that remains is now trapped within the few kilometres width of the suture zone. Investigations of terranes within the suture provide insights into the architecture and evolution of the Tethyan Ocean interior.

The evolutionary history of the Neotethys has been inferred from the continuous sedimentary record preserved in the northcrn Indian passive margin series (Gaetani \& Garzanti 1991; Liu \& Einsele 1994). However, this interpretation addresses only the sedimentary response to multiple rifting events along the southcrn Neotethyan margin. The depositional history and architecture of the central Ncotethyan domain remains unexplored. Although the movement of India towards Eurasia is well documented from magnetic anomalies on the Indian Ocean floor and other magnetic data (Klootwijk et al. 1992), the sequence of events that accompanicd India-Asia convergence is thus far poorly understood especially in the castern (Tibetan) segment of Neotethys. In spite of an early suggestion (Allegre et al. 1984; Proust et al. 1984) of the possibility of intra-Tethyan subduction in this sector of Tethys, the later and more widely accepted model (Searle et al. 1987) assumes that the entire north-south extent of oceanic lithosphere was subducted along the southern margin of the Lhasa terranc. Summaries of the structure and evolution of this region appear somewhat dissimilar to those for areas further west (Kohistan and Ladakh), where the Spontang and Kohistan-Dras volcanic ares, associated with intra-oceanic subduction, are well documented (Searle et al. 1987, 1999; Corficld et al. 1999). The simplified account of the castern part of the Neotethys has recently been reassessed with the recognition of remnants of an intra-oceanic subduction system (Aitchison et al. 2000; McDermid et al. 2002) and seismic tomographic images under the region (Van der Voo el al. 1999).

In this paper, we present the results of detailed geological mapping, and structural and radiolarian biostratigraphic studics of the Bainang terrane. The terrane developed as a subduction 
complex, on the southern edge of a south-facing intra-oceanic subduction system, which grew above a northward-subducting slab of Neotethyan ocean lithospherc. Facics of the central Neotethyan domain were accreted into this subduction complex. New data elucidate the tectonic setting and evolution of this terrane, and they are interpreted in terms of depositional setting and the mode and timing of subduction-related accretion. We contrast the geological development of the Bainang terrane with that of other terranes in the region and consider this in the broader context of Neotethys evolution.

\section{Regional tectonic framework}

Six tectonostratigraphic units (terranes) that developed prior to India Eurasia collision are recognized within and bounding the Yarlung - Tsangpo suture zone (Fig. 1). From north to south, we bricfly outline their nature and key features related to the cvolution of the Tethys, following the nomenclature introduced by Aitchison et al. (2000).

The Lhasa terrane is a microcontinental block that had detached from the northern periphery of Gondwana and docked with Asia by the Late Jurassic--Early Cretaceous (Allegre et al. 1984; Yin \& Harrison 2000). Middle Proterozoic to Lower Cambrian metamorphic basement is overlain by Palaeozoic to middle Cretaceous shallow-marine and terrestrial deposits. The southern margin of the terranc bounds the Yarlung-Tsangpo suture zone and consists of an Upper Jurassic-Lower Cretaccous metasedimentary and metavolcanic basement (Sangri Group) overprinted by Andean-type intrusive and volcanic rocks of the Gangdese batholith (Badengzhu 1979; Burg \& Chen 1984). These igneous rocks record the extensive magmatism that resulted from northward subduction of Neotethyan oceanic lithosphere bencath the Lhasa terrane. Radiometric ages from Gangdese plutons range from $153 \pm 6$ Ma (Murphy et al. 1997) to $30.4 \pm 0.4 \mathrm{Ma}$ (Harrison el al. 2000). Sangri Group andesites are intercalated with clastic and carbonate deposits bearing Upper Jurassic-Lower Cretaceous fossils (Badengzhu 1979; Pearce \& Mei 1988; Bureau of Geology and Mineral Resources of Xizang Autonomous Region 1993). Radiometric ages for the andesites, rhyolites and ignimbrites of the Takena and Lingzi- zong formations range from 119 to 38 Ma (Maluski et al. 1982; $\mathrm{Xu}$ et al. 1985; Miller et al. 2000). Both radiometric and biostratigraphic data appear to indicate that subduction-related magmatism along the southern margin of the Lhasa terrane commenced in the Late Jurassic and lasted until mid-Oligocene time.

The Xigaze terrane incorporates a $5000-8000 \mathrm{~m}$ thick succession of volcaniclastic turbidites (Xigaze Group flysch) deposited to the south of the Lhasa terrane. Rare fossils indicate an upper Albian (Wicdmann \& Dürr 1995) to Coniacian (Wan et al. 1998) stratigraphic range although younger deposits have probably been removed by crosion. These rocks arc interpreted as a forearc succession that developed in association with north-directed subduction beneath the Lhasa terrane (Shackleton 1981; Burg \& Chen 1984; Girardeau et al. 1984; Einsele et al. 1994; Dürr 1996)

The Zedong terrane was recognized by Aitchison et al. (2000) near Zedong and Luobusa. It occurs as a tectonic sliver between the Lhasa and Dazhuqu terranes and is bounded by northdirected thrusts related to the Renbu-Zedong thrust system of Harrison et al. (2000). The terrane incorporates a succession of arc tholeiitic lavas overlain by a thin $(c .15 \mathrm{~m})$ sequence of red ribbon-bedded chert then $c .1000 \mathrm{~m}$ of volcaniclastic breccias cut by numerous andesite dykes and minor intrusions of diorite and leucogranite (McDermid et al. 2001; McDermid 2002). Rocks within the terrane have been interpreted as remnants of an intraoceanic volcanic arc (Aitchison ef al. 2000; McDcrmid et al. 2001; McDermid 2002) similar to other terranes known from elsewhere along the suture in the NW India and Pakistan arc (Corficld et al. 2001). Both radiometric and biostratigraphic data indicate the onset of magmatism in the late Mid-Jurassic. Radiometric ages (McDermid et al. 2002) are in accord with Bajocian-lower Callovian radiolarian faunas in the underlying chert. Complexity is indicated by reports (Badengzhu 1979) of rare Lower Cretaceous marine fossils from volcaniclastic strata and confirmed by our investigations of radiolarian faunas.

The Dazhuqu terrane comprises a series of ophiolitic bodics traceable along the Yarlung-Tsangpo suture zone with major outcrops in the Xigaze and Luobusa areas (Aitchison et al. 2004). Near Zedong and Luobusa ophiolitic rocks are faulted

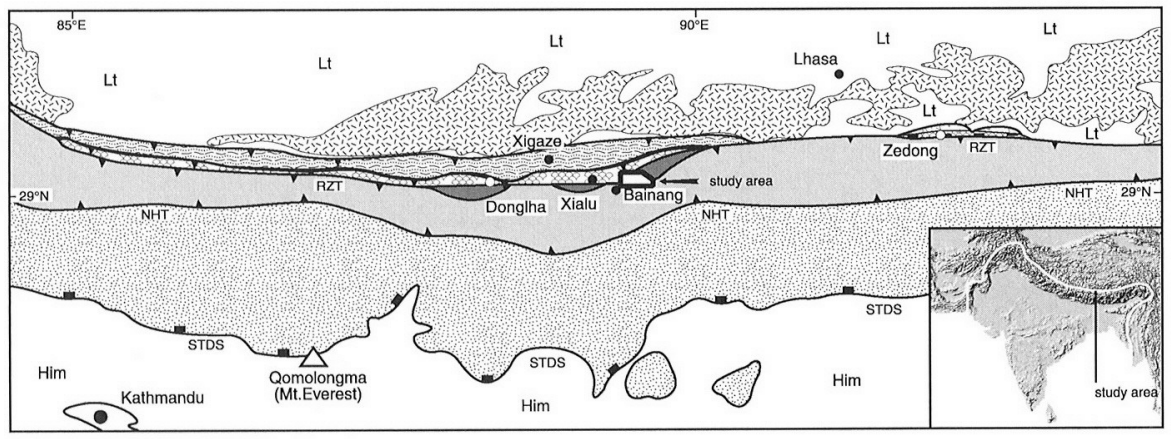

LHASA TERRANE

Lt Paleozoic to Tertiary rock units

Gangdese batholith

YARLUNG TSANGPO SUTURE ZONE

Xigaze terrane

Zedong terrane

Dazhuqu terrane

Bainang terrane
INDIAN SUBCONTINENT

Continental rise deposits

Shelf deposits

Him Himalayan metamorphic rocks FAULTS

$\square$ - area mapped in detail (Fig. 2)

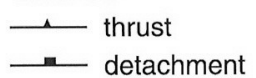

Fig. 1. Tectonic zonation of the central part of the Yarlung-Tsangpo suture zone, southern Tibet, and location of study area. Modified from Geological Map of Xizang (Tibet) Autonomous region, PRC (Bureau of Geology and Mineral Resources of Xizang Autonomous Region 1993) and figures of Le Fort (1996) and Yin \& Harrison (2000). RZT, Renbu Zedong Thrust (or Great Counter Thrust); NHT, North Himalayan Thrust; STDS, South Tibet Detachment System. 
against the Zedong terrane or thrust northwards over lowermost Miocene conglomerates developed along the southern margin of the Lhasa terrane (Aitchison et al. 2002). In the Xigare district, the ophiolite is thrust northwards over the Xigaze terrane (Burg 1983; Wang et al. 1987). The southern margin of the terrane lies, in most areas, at the Miocene north-directed Renbu Zedong thrust (Yin et al. 1994, 1999), which places Indian terrane rocks over the ophiolite. In the Bainang district, where there is an Sshaped sigmoidal bend in the Yarlung Tsangpo suture zone, earlier contacts can be observed at south-directed thrusts that are locally truncated by strikc-slip faults (Girardeau et al. 1985a; Ratschbacher et al. 1994).

Several ophiolitic massifs, in the Xigaze area, form a nearly continuous belt over $150 \mathrm{~km}$ long and up to $25 \mathrm{~km}$ wide. Ophiolitic sections are mostly north-facing with the sequence repeated across dextral strike-slip faults. Although tectonically disrupted and heavily altenuated, sections locally display a complete ophiolitic scquence from fresh $\mathrm{Cr}$-diopside-rich harzburgites to marine sedimentary cover on mafic volcanic rocks (Nicolas et al. 1981; Girardeau et al. 1984, 1985a, b). Radiolarian biostratigraphy constrains the timing of eruption of ophiolitic basalt to the late Barremian-early Aptian (Zyabrev et al. 1999; Ziabrev et al. 2003). Aitchison et al. (2000) interpreted the Dazhuqu terrane ophiolite as having originated in an intraoceanic suprasubduction zone setting and this is supported by detailed mineralogical and petrochemical studies in the Xigaze area (Hćbcrt et al. 2000, 200 1).

The Bainang terrane, on the southern side of the suture zonc, was interpreted by Aitchison ef al. (2000) as a subduction complex, and is the subject of this paper. It contains units previously referred to as infra-ophiolitic thrust sheets of radiolarites (Burg \& Chen 1984) or Upper Jurassic -Lower Cretaceous red radiolarites (Girardeau et al. 1984). The terrane is bounded to the north by ophiolitic rocks of the Dazhuqu terrane and to the south by the Indian terrane. Good cxposures exist near Donglha, Xialu and Bainang (Fig. 1). In most sections studied, the terrane is chert dominated and is characterized by a northfacing tectonic pile of oceanic lithologies repcated by a series of south-verging imbricated slices. Radiolarians reported from siliccous rocks near Xialu range in age from the Mid-Jurassic to midCretaccous (Aptian) (Wu 1993; Matsuoka et al. 2001, 2002).

Passive margin rocks of the Indian terrane or Tethyan (Tibetan) Himalaya lic south of the suture. Thick Permian to Cretaceous continental rise deposits (Liu \& Einsele 1994) merge southward into a continuous Ordovician to Eocenc shelf sedimentary succession of marine carbonate, sandstone, siltstone and shale (Bureau of Gcology and Mineral Resources of Xizang Autonomous Region 1993; Jadoul et al. 1998). Ordovician-Early Permian epicontinental deposition in shallow seas linked to Tethys terminated with rifting that evolved into detachment of Peri-Gondwana microcontinents and, ultimately, the opening of Tethys. The Mesozoic scquence records increased tectonic subsidence in the Carnian-Norian, followed by building of carbonate platforms. Drowning along the entire length of the carbonate platform occurred in the early Callovian with deposition of oolitic ironstone superseded by Late Jurassic deposition of black shales (Gactani \& Garzanti 1991; Jadoul et al. 1998). The development of the passive continental margin facing the Tethyan domain was punctuated by a series of rifting episodes related to Gondwana disintegration and associated with intraplate volcanism (Gaetani \& Garzanti 1991). In correlative sections of the western Himalaya, the Zanskar shelf merges northward with Mesozoic slope-rise deep-sea deposits of the Lamayuru Com- plex and its distal equivalent, the Karamba Complex (Danelian \& Robertson 1997; Robertson \& Sharp 1998).

The original disposition of terranes within the Yarlung Tsangpo suture zone has been greatly disrupted and former relations between terranes ate not well constrained. Therefore, reconstruction of the tectonic evolution of the area is difficult. Most carly models invoked the existence of a single Andean-type convergent plate margin along the northern side of Neotethys but analogy with the modern western Pacific and SL $\Lambda$ sia suggests that reality may have been considerably more complex. Development of the Xigaze terrane is interpreted as having been related to evolution of the magmatic are along the southern edge of the Lhasa terrane (Einscle ef al. 1994; Dür 1996). The Xigare terrane was formerly regarded as being floored by the Dazhucu ophiolite (e.g. Burg \& Chen 1984; Girardeau ef al. 1984; Iinsele et al. 1994; Dürr 1996), but these two units are ubiquitously in tectonic contact and there is no a priori reason why they should have been genetically related (Aitchison et al. 2000). The cooccurrence and remarkably consistent north south distribution of the broadly coeval Zedong (magmatic arc), Dazhuqu (forearc ophiolite) and Bainang (subduction complex) terranes led to their interpretation as evidence for a south-facing intra-oceanic subduction system that lay within the Neotethys (Aitchison et al. 2000 ) and the existence of more than one convergent margin. As more details and constraints on the evolution of terranes within the Yarlung Tsangpo suture zone become available the complexity and sophistication of models for this zone increase.

\section{Methods}

Preliminary examination of the Bainang terrane at several sections revealed a structural style and lithologies reminiscent of subduction complexes. The most complete section oceurs near Balinang and this was selected for delailed study because of excellent exposures. This area was mapped in detail $(1: 25000)$ to discern map-scale struetures and obtain a solid basis for structural and biostratigraphic data and interpretations. Special attention was paid to the nature of contacts between different lithologies. Depositional contacts are locally preserved and these were used to reconstruct an oceanic plate stratigraphy. Radiolarian biostratigraphy was applied as a key method to constrain ages and als a means of cross-checking the reconstructed lithostratigraphic succession established during field-mapping. All prospective lithologies were extensively sampled with sedimentological features and details of mesoscopic structural patterns documented. Individual traverses were sampled systematically along continuous profiles to clarily structure and trace possible age progressions. Radiolarians were pieked from dilute Ilf and/ or ICl acid residues, and imaged using a IJitach Sl:M. Identification of taxa and age assignment for Middle Jurassic to middle cretalcous radiolarian assemblages are based on recent taxonomic study and biostratigraphic zonation of Tethyan radiolarians (Jud 1994; $0^{\circ} \mathrm{D}$ )ogherty 1994; Baumgartner ef al. 1995). For Lower Juassic and Triassic assemblages other zonal schemes (Pessagno \& Whalen 1982; Kislida \& Hisada 1985; Yeh 1987; Carter et al. 1988; Ilori 1990; Carter 1993) were applied. Over 130 radiolarian-based ages were acquired in the course of this study.

\section{Bainang terrane}

A NE-SW-oricnted, $35 \mathrm{~km}$ long tectonic lens of Bainang terranc rocks is preserved at a well-developed bend in the trace of the Yarlung-Tsangpo suture zone located cast of the township of Bainang. Exposure pinches out tectonically near Bainang in the west and eastwards towards Dazhuqu. The terrane is bounded to the NW by the Dazhuqu terrane. The contact is a south-directed thrust that dips $60 \cdot 70^{\circ} \mathrm{NW}$ and places an ophiolitic assemblage in the hanging wall over the Bainang terrane. To the south, the 
Bainang terrane is juxtaposed, along another moderately to stceply $\left(45-85^{\circ}\right)$ dipping south-directed thrust, over a footwall of Indian terrane lithologies. The overall geological structure within the tcrrane is that of an imbricate thrust stack containing numerous north-facing and chiefly south-verging tectonic slices. Slices incorporatc oceanic pelagic and hemipelagic lithologies such as chert, siliccous, calcarcous and tuffaceous mudstone, limestone, and siliceous and calcareous shale. Individual thrust slices are thin $(5-60 \mathrm{~m})$ and pinch out over short distances. Units shown on the geological map and cross-sections (Fig. 2) represent distinctive packages of these slices in which similar lithologies are tectonically stacked. Some packages are internally deformed by folds on various scales and shearing is widespread. Deformation intensity increases progressively from NW to SE across strike. The abundance of widely spaced layer-parallel shear zones increases until an anastomosing cleavage peaks with development of a strong foliation in the SE. An east--weststriking sinistral strike-slip fault locally truncates the southern margin of the Bainang terranc where it offsets $1 \mathrm{~km}^{3}$ size fragments of the Dazhuqu terrane by at least $20 \mathrm{~km}$. Four NWSE-striking faults diagonally crosscut the western part of the mapped area with sinistral offsets of $250-500 \mathrm{~m}$ and are synthetic to the sinistral strike-slip fault along the southern flank of the terrane. Late strike-slip faulting is interpreted as related to collisional deformation (Ratschbacher et al. 1994).

\section{Stratigraphy and structure}

Original lithostratigraphic sections within the terrane are heavily disrupted but this is compensated for by exceptional exposure. Sufficient original contacts betwecn lithologies can be locally observed such that the original stratigraphic succession is determinable with reasonable confidence. Much of the terrane is structurally disrupted but block-in-matrix style mćlange is rare. Dctailed ficld investigation permits the recognition of five mappable lithotectonic units in the Bainang area. Their discrimination is based on the proportions of characteristic lithologies, and structural style (Table 1). From north to south, the units are the Bangga, Zongxia, Maniga, Yalongmai and Renchingang units. Structural variation permits recognition of the Sakabu and Tsashibu subunits within the Maniga unit and the Chiangdui and Baigang subunits in the Yalongmai unit. All names are taken from local villages situated close to outcrops of each unit. In general, units trend NE-SW. Overlap between consecutive units is somewhat discordant and individual units wedge out along strike (Fig. 3). The two northern units have similar stratigraphic records that differ noticeably from the other three. Accordingly, units are combined into the northern and southern tracts.

Bangga unit. The structurally highest unit is oriented ENE and crops as a narrow $(0.5-0.7 \mathrm{~km})$ zone. Much of the northwestern extent of the unit, and its contact with the Dazhuqu terrane, is covered by Quaternary alluvium. Red radiolarian chert is overwhelmingly dominant, mostly ribbon-bedded $(1-12 \mathrm{~cm}$, average $3-5 \mathrm{~cm}$ bed thickness), and occurs as monotonously repeated couplets of chert and thin siliceous claystone. Some rare, thin $(0.5-1 \mathrm{~m})$ chert horizons are greyish green. Subordinate massive or thickly $(20-50 \mathrm{~cm})$ layered olive-grey to greenish grey siliceous mudstone occurs throughout the unit. Mudstones are locally tuffaccous. Purplish red siliceous mudstone consists of thin $(2 \cdots 7 \mathrm{~cm})$ layers of clay and siliceous material. Layering is commonly accentuated by tuffaceous laminac and thin $(0.5-$ $4 \mathrm{~cm}$ ) felsic tuffs. Structural disruption is intense and only portions of any sections are stratigraphically coherent; nevertheless, where rare original depositional contacts are preserved, siliceous mudstoncs overlie the red radiolarian cherts.

Scattered shear zones bounding relatively coherent chert lenses characterize the structure of the Bangga unit. On slopes where exposure is excellent, these cherts crop out in thick (tens of metres) slices or conjugate tectonic lenses. Contacts between chert and siliceous mudstones are typically tectonic. Shear surfaces parallel bedding on outcrop and map scalcs (Fig. 3). Bedding and shear surfaces typically dip moderately to steeply $\left(50-85^{\circ}\right)$ NNW. Rare south-dipping sections represent overturned limbs of large open recumbent folds interpreted to be associated with ramps and flats of thrusts. Small-scale asymmetric S- and Z-shaped intrafolial folds deform layering in the cherts. Fold morphologies and hinge oricntations indicate south-directed thrusting with components of sinistral or dextral along-strike displacement. Some folds display pure dextral or sinistral displacement.

Red radiolarian cherts are characterized by poorly to moderatcly preserved radiolarian assemblages, whereas preservation is generally better in siliceous mudstones. Radiolarians were identified from 47 chert samples mostly collected along two traverses, and from 10 samples of overlying siliceous mudstones at various localities. Biostratigraphic data (Figs 4 and 5) cstablish the age ranges of units within the lithostratigraphy. They indicate that the cherts range from Rhaetian (Upper Triassic) to lower Barremian (Lower Cretaceous). Siliccous mudstones occupy a narrow middlc Aptian (mid Cretaceous) stratigraphic interval. No systematic progression in ages was observed across the unit and large age

Table 1. Characteristics of lithotectonic units

\begin{tabular}{|c|c|c|}
\hline Unit & Lithological characteristic & Structural style \\
\hline \multicolumn{3}{|l|}{ Northern tract } \\
\hline Bangga & Predominant red radiolarian cherts; subordinate siliceous mudstone & Scattered shear zones bounding tectonic slices and lenses \\
\hline Zongxia & $\begin{array}{l}\text { Predominant greenish grey (rare varicoloured) siliceous mudstone; } \\
\text { subordinate red radiolarian cherts }\end{array}$ & Conjugate tectonic lenses bounded by shear zones \\
\hline \multicolumn{3}{|c|}{ ( } \\
\hline Maniga & $\begin{array}{l}\text { Predominant varicoloured tuffaceous chert and mudstone; common } \\
\text { varicoloured mudstones; subordinate red radiolarian cherts, } \\
\text { ferruginous chert, calciturbidite and micritic limestone }\end{array}$ & $\begin{array}{l}\text { Intense shearing with phacoidal and } \mathrm{S}-\mathrm{C} \text { fabrics; intensity of } \\
\text { shearing progressively increases southwards (across strike) }\end{array}$ \\
\hline Yalongmai & $\begin{array}{l}\text { Predominant varicoloured calcareous shales; common varicoloured } \\
\text { siliceous shales and sheared red radiolarian chert; subordinate } \\
\text { calciturbidite and micritic limestone }\end{array}$ & $\begin{array}{l}\text { Zonal to penetrative foliation with stretching lineation deformed } \\
\text { by later sporadically developed crenulation and abundant kink } \\
\text { bands }\end{array}$ \\
\hline Renchingang & $\begin{array}{l}\text { Predominant grey and yellowish grey calcareous shales; subordinate } \\
\text { varicoloured calcareous shales, calciturbidite and red radiolarian chert }\end{array}$ & $\begin{array}{l}\text { Penetrative foliation with stretching lineation deformed by later } \\
\text { sporadically developed crenulation and abundant kink bands }\end{array}$ \\
\hline
\end{tabular}




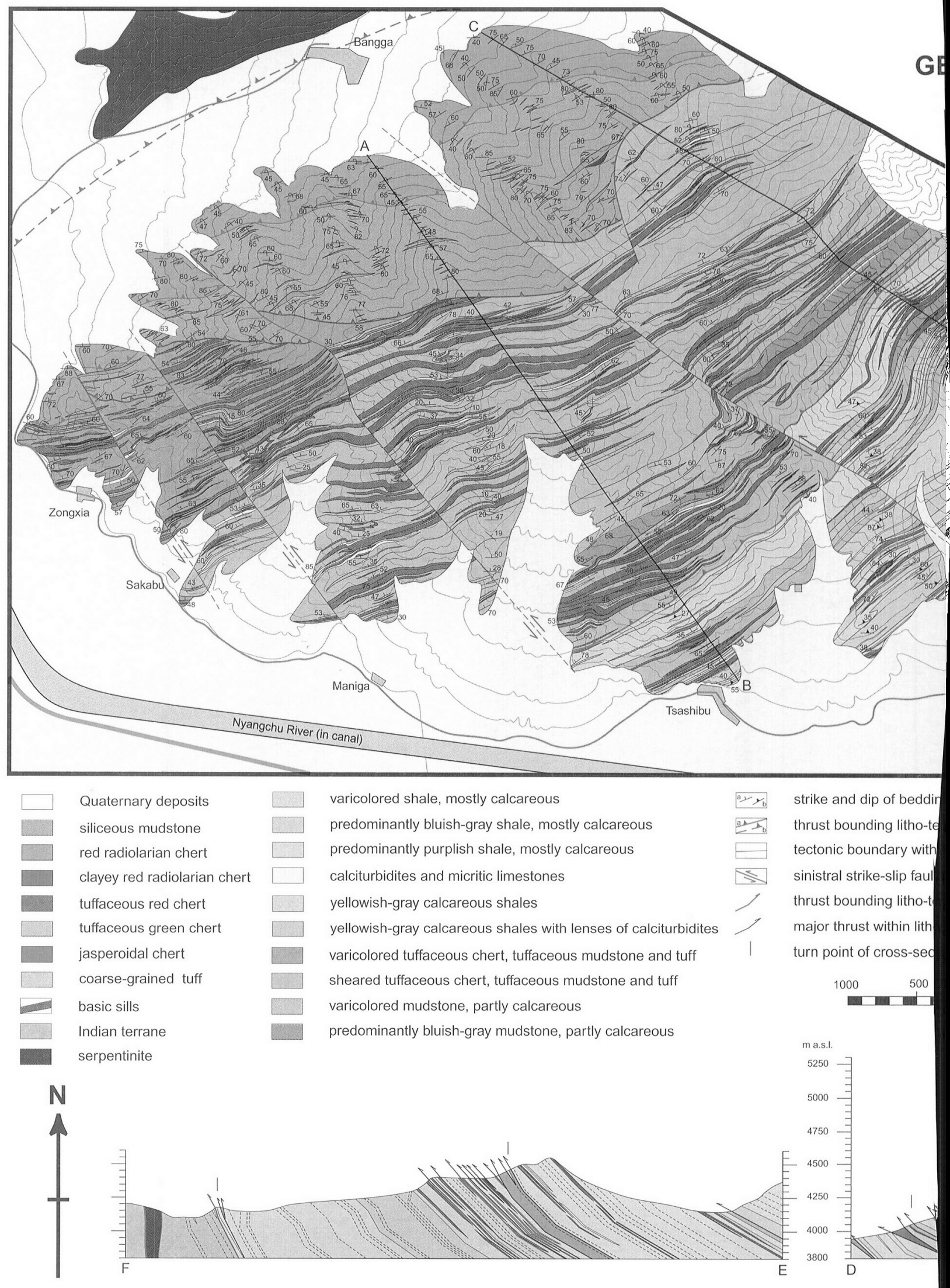

Fig. 2. Geological map and cross-sections of the Bainang terrane in the Bainang area, Yarlung-Tsangpo suture zone, southern Tibet. 


\section{OLOGICAL MAP OF THE BAINANG DISTRICT, YARLUNG-TSANGPO}

SUTURE ZONE, SOUTHERN TIBET (XIZANG), CHINA

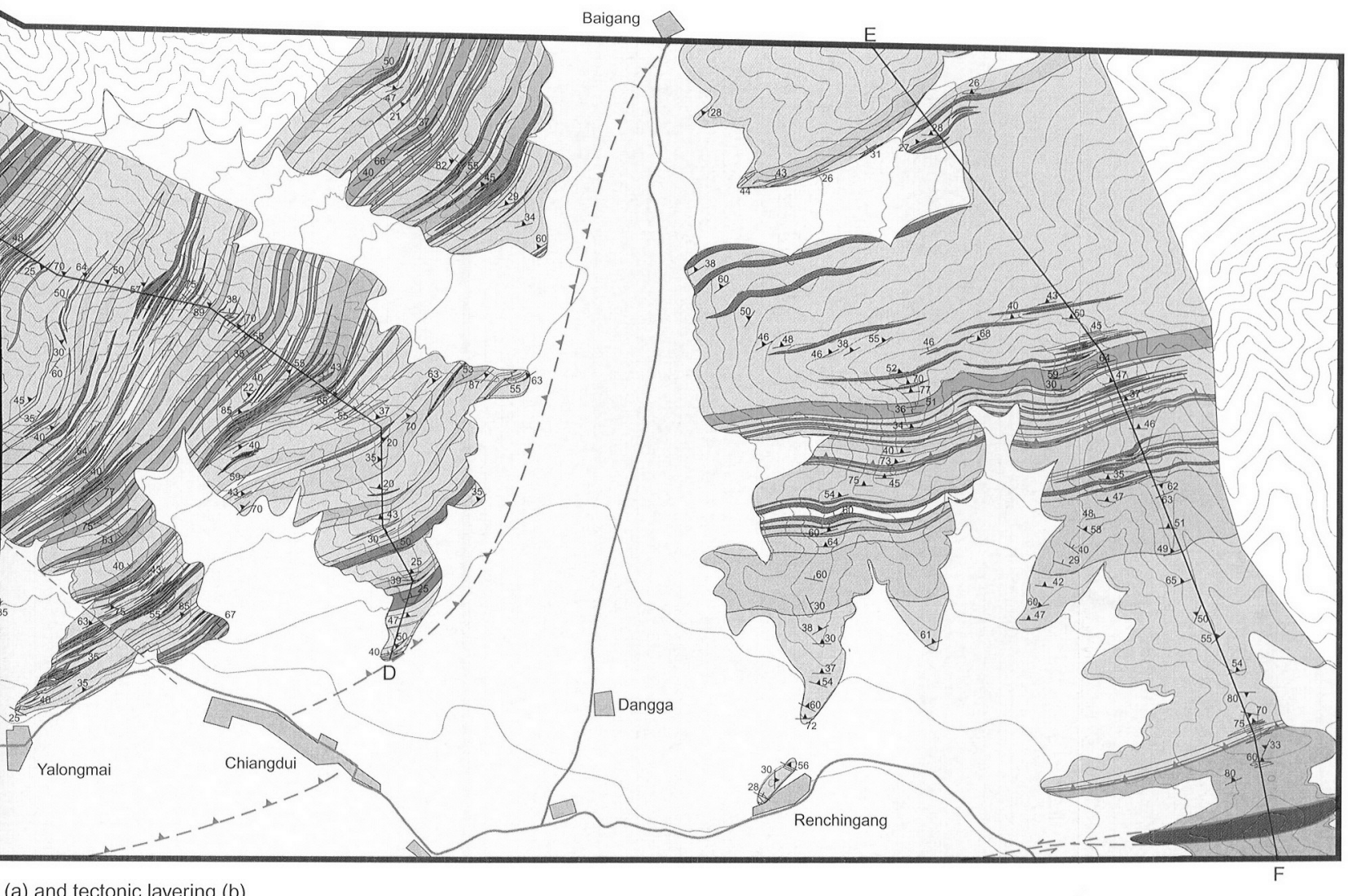

(a) and tectonic layering (b)

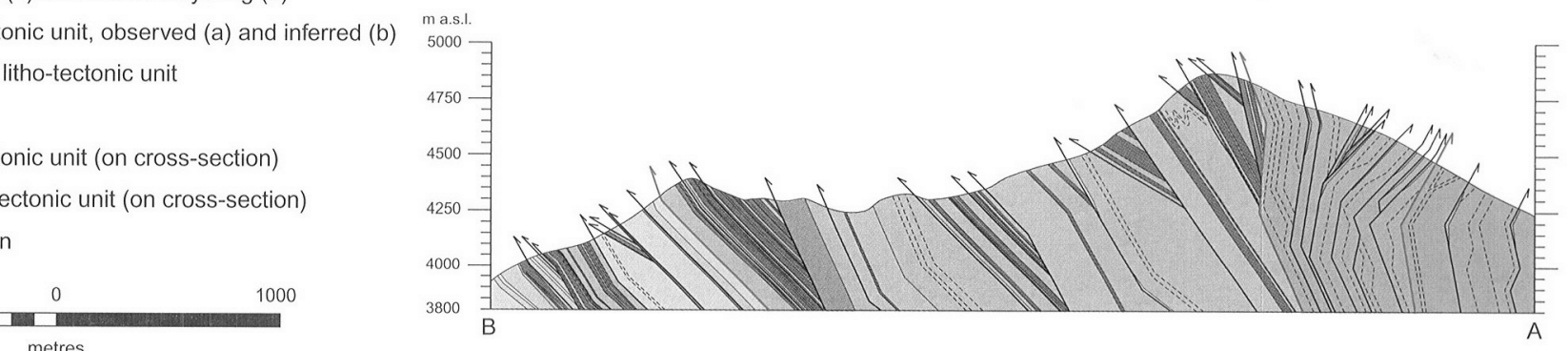




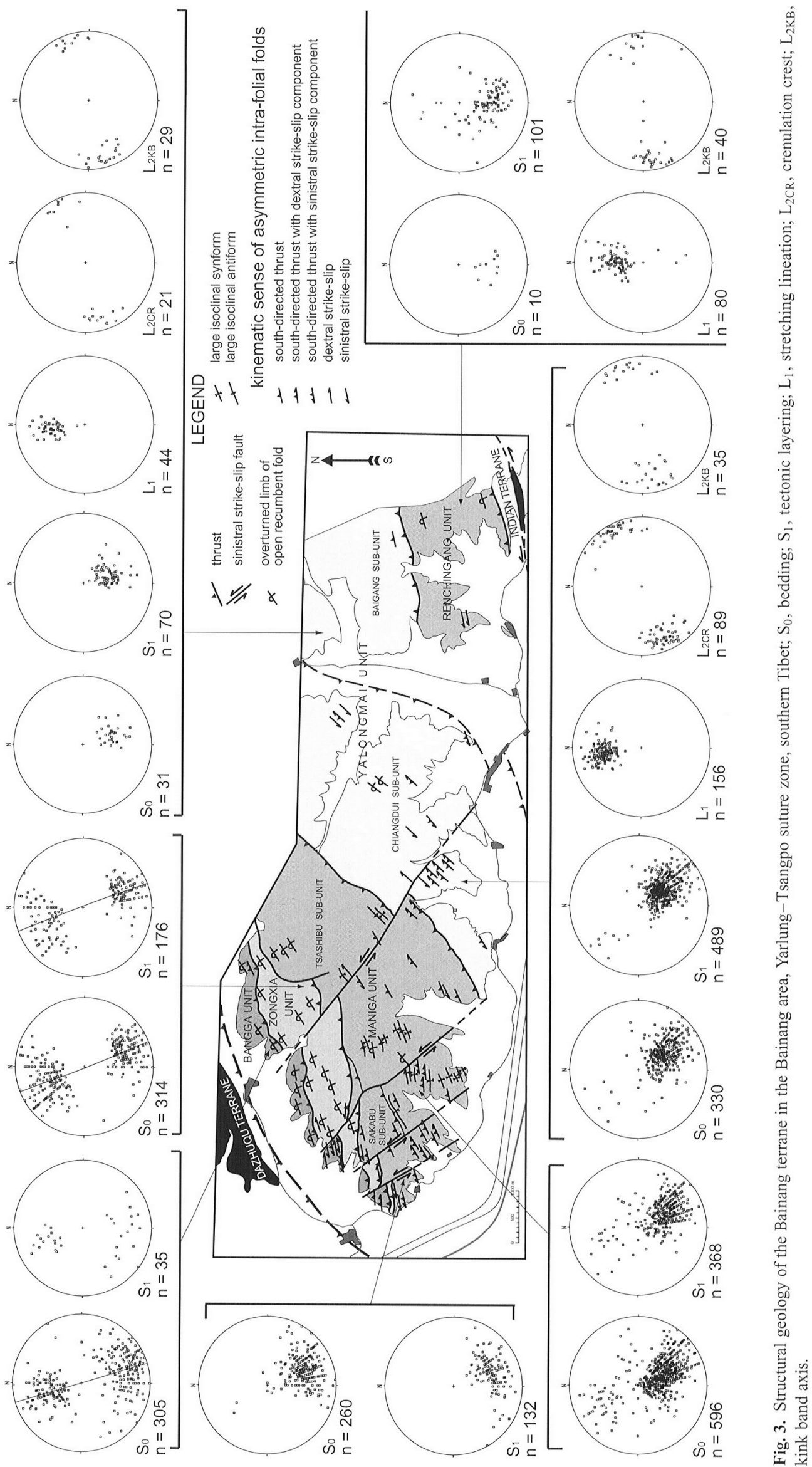



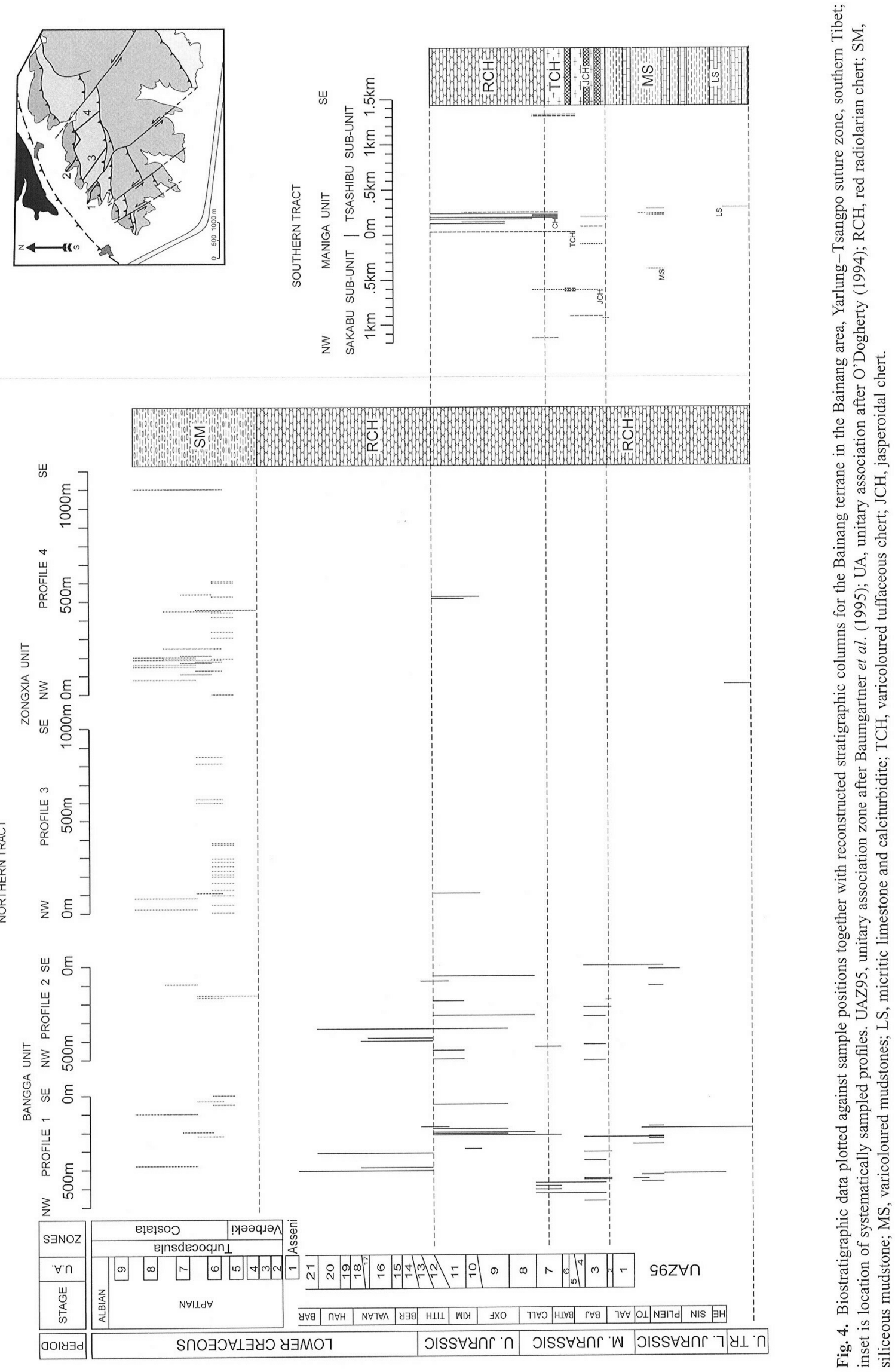
offsets probably occur within lithologically homogeneous chert sections.

Zongxia unit. This unit contains lithologics similar to those of the Bangga unit but in different proportions. Rare depositional contacts indicate a similar lithostratigraphic succession although original relations between the red radiolarian chert and other lithologies could not be confirmed. Olive-grey to greenish grey, massive to faintly layered, siliceous mudstones predominate. These mudstones are up to $10 \cdots 15 \mathrm{~m}$ thick although shearing precludes accurate estimation of the original thickness. Intercalations of thin $(2-4 \mathrm{~cm})$ layers of dark green chert locally occur within the mudstoncs. Fine parallel, wavy, or small-scale ripple cross-laminations indicate the influence of bottom traction currents. Some siliceous mudstones are tuffaceous. Layers (4-$20 \mathrm{~cm}$ thick) of felsic tuff with graded bedding occur and are most abundant in the central portion of the unit, where thicker ( $12.5 \mathrm{~m}$ ) composite tuff layers contain rip-up clasts and lamination indicative of turbidity current deposition. Stratigraphically underlying, purplish red siliceous mudstones are up to $5-6 \mathrm{~m}$ thick and thinly $(2-7 \mathrm{~cm})$ layered. Thin tuffs accentuate layering. Horizons of centimetre-thick purplish grey chert with abundant radiolarians oceur within this mudstone. Multiple repetitions of the succession are tectonic rather than depositional. Red radiolarian chert occurs within tectonic lenses a few tens of centimetres to $50 \mathrm{~m}$ thick. Chert is mostly ribbon-bedded and identical to that in the Bangga unit. Shearing and development of quartz veins is common, cspecially in smaller bodies.

Structural style is characterized by the development of numerous shear zones bounding conjugate tectonic lenses and is observable on both outcrop and larger scales. It is accentuated by abundant chert lenses of various sizes within the siliccous mudstones. Shear zones bound chert lenses and are extensive within tectonically thickened sections of siliceous mudstones. Shear surfaces mostly parallel bedding and dip moderately to stecply $\left(50-80^{\circ}\right)$ NNW. Local overturning occurs on the limbs of large, open recumbent folds. Fold closures are angular or complieated by smaller folds of the same morphology. Smallscale S- and Z-shaped intrafolial folds similar to those in the Bangga unit are also present.

Siliccous mudstones (45 samples) and chert lenses (four) yiclded well-preserved, datable radiolarians. The distribution of ages is complex, with numerous repetitions across the unit indicating tectonic imbrication, which characterizes the structural style. Although biostratigraphic data for the red cherts are scarce, they constrain the oldest known chert as Upper Triassic (Rhactian) with a total range for this lithology to Upper Jurassic. All siliceous mudstoncs occupy a narrow middle Aptian stratigraphic interval. The transition from chert to siliceous mudstone accumulation lies within the lowermost Aptian. The reconstructed stratigraphic column for the Zongxia unit is similar to that for the Bangga unit. A more continuous Lower Cretaceous chert sequence is well preserved along strike in correlatives of this unit near Xialu $25 \mathrm{~km}$ west of Bainang (Wu 1993; Matstoka et al. $2001,2002)$ and confirms our interpretation of the original lithostratigraphic suecession. Our samples of siliceous mudstone from near Xialu have also yiclded well-preserved middle Aptian radiolarians.

Maniga unit. This unit has a maximum width of about $3 \mathrm{~km}$ and is oriented at a slight angle to the structurally higher Zongxia unit such that its NW flank is progressively overlapped in an ENE direction. Lithologies differ from those in units to the north, although red radiolarian chert is also present. It is further subdivided into the Sakabu and Tsashibu subunits based on differing structural styles and proportions of constituent lithologies. Three lithological associations are present: (1) varicoloured mudstones intercalated with micritic limestones and calciturbidite; (2) varicoloured tuffaceous cherts intercalated with jasperoidal chert, tuffaccous mudstone and tulf; (3) red radiolarian chert. Tuffaceous chert and mudstone predominate with jasperoidal cherts more abundant in the Sakabu subunit and varieoloured mudstones and calcarcous rocks forming up to $20 \%$ of the Tsashibu subunit

Red (purplish red) or bluish grey varicoloured, locally calcarcous, mudstones occur in roughly equal proportions and exhibit multiple fault repetitions. Rare thin $(0.5-1.5 \mathrm{~cm})$ layers of chert are also present. Micritic pale pink or bluish grey limestones are massive or thinly bedded and occur as rare individual beds or horizons $(0.4-5 \mathrm{~m}$ thick) within successions of varicoloured mudstones. Calciturbidite beds $(520 \mathrm{~cm})$ occur in successions up to $10 \mathrm{~m}$ thick. Ripple cross-laminations indicate sediment transportation from the south. Layers $(38 \mathrm{~cm})$ of micritic limestones and finc-laminated siliceous-calcareous rocks occur within calciturbidites. Most contacts between these lithologies and those described below are tectonic

Ribbon-bedded varicoloured tuffaceous chert occurs as couplets of tuffaccous chert $(<15 \mathrm{~cm})$ and thinner mudstone layers in sequences $<20 \mathrm{~m}$ thick. Radiolarians are scarce. Tuffaccous mudstones and tuffs occur in thick layers $(20 \cdots 300 \mathrm{~cm})$ intercalated within tuffaceous chert sequences. Coarse-grained (lapilli) tulf is of basic composition. Jasperoidal chert crops out as thin $(2-7 \mathrm{~m})$ zones of elay and hematite-rich layess ( $1.4 \mathrm{~cm})$ within varicoloured tuffaccous cherts, and is mostly red with rare dark grey layers and devoid of radiolarians. Some primary depositional contacts between red jasperoidal ehert, tuffaceous mudstone and varicoloured tuffaceous chent remain. Red radiolarian cherts are the uppermost stratigraphic units. They are similar to those in the Bangga unit and typically oceur as tectonic lenses.

Anastomosing shear zones bounding conjugate tectonic lenses several metres thick characterize the Sakabu subunit. Lenses incorporate varicoloured tuffaceous cherts intercalated with tuffaccous mudstone and tuff. Zones $(0.510 \mathrm{~m})$ of intensely sheared caleiturbidites are commonly sandwiched between these lithologies. Shear intensity increases southward and tectonic lenses become smaller. A prominent thrust with a large synform in its footwall marks the boundary between subunits. In the Tsashibu subunit, more intense and pervasive shearing is associated with development of phacoidal and S C Fabrics in tectonically interleaved lithologies. Foliation is locally developed in the $\mathrm{SE}$.

Dips to the NNW predominate amongst both shear surfaces and bedding. Local variations and overturning indicate the presence of large open folds. Small-scale S- and 7-shaped intrafolial folds occur throughout the unit. Morphology and hinge orientations indicate south-directed thrusting with components of sinistral or dextral along-strike displacement. Intrafolial folds developed during different phases of deformation, as some deform bedding and shear surfaces whereas others deform only bedding and predate tectonic layering. This probably reflects non-uniform differential movements of particular tectonic slices rather than discrete stages of homogencous deformation of the cntire unit. Large tight or isoclinal folds with limbs several tens of metres long oceur locally. They deform both bedding and shear surfaces, and usually warp tectonic slices. These folds are usually complicated by parasitic lolds and are characterized by north-dipping axial planes and near-horizontal hinge lines. They 


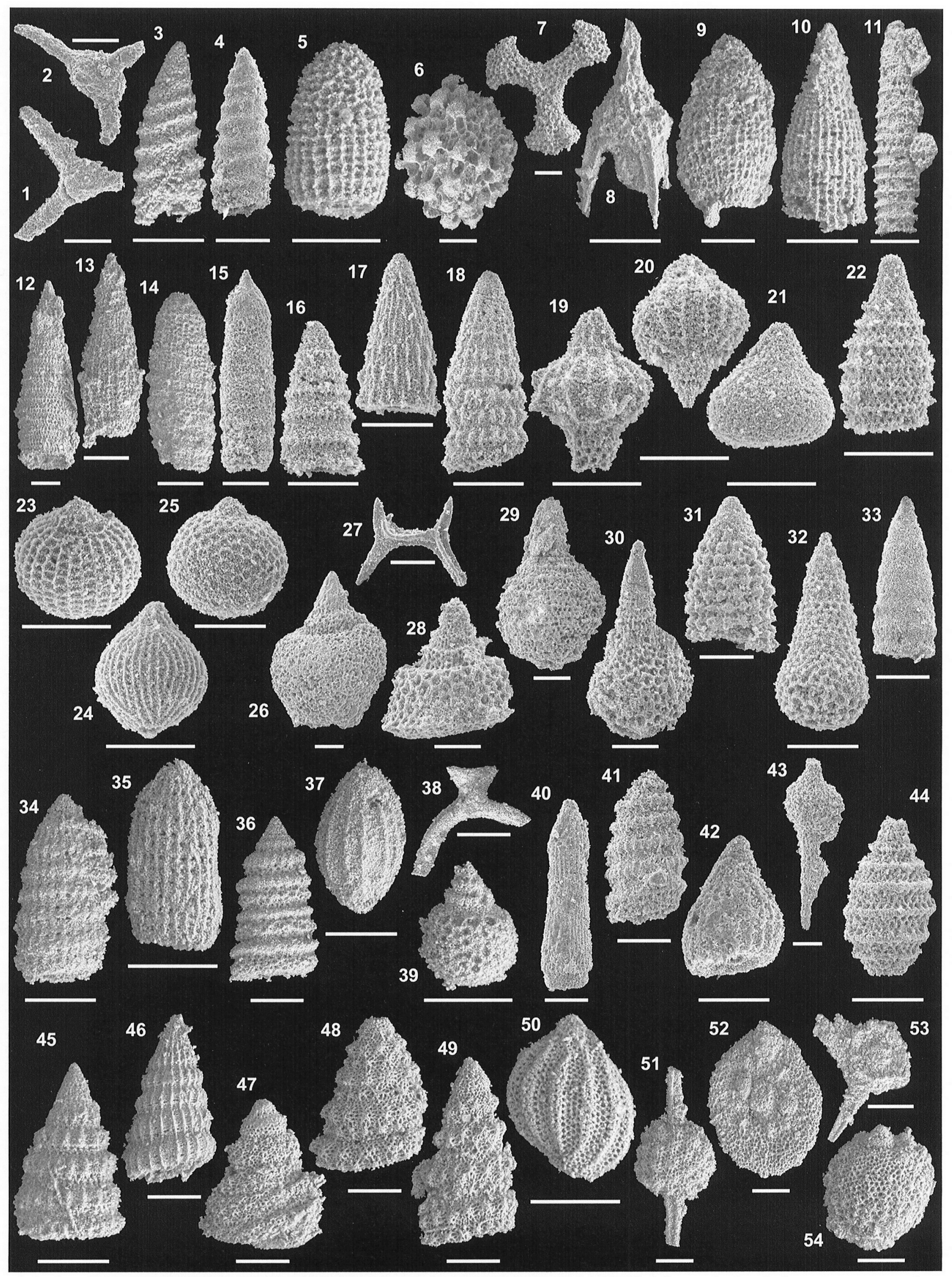


appcar as solitary synforms or multiple folds. Within conjugate synform--antiform pairs, synforms are always structurally lower, consistent with large Z-shaped folds (as seen from the west) indicating south-directed thrust displacement. Development of such folds was related to progressive thrusting alter wedge imbrication.

Although the Maniga unit was extensively sampled, it yielded few well-preserved radiolarians. When scarce biostratigraphic data are combined with ficld observations of lithostratigraphy, they confirm our interpretation of the original succession. Varicoloured upper Norian-Rhactian to upper Aalenian mudstones are intercalated with micritic limestones and calciturbidites and overlain by varicoloured upper Aalenian to Bathonian tuffaceous cherts intercalated with jasperoidal cherts, tuffaceous mudstone and tuff. Callovian to Oxfordian-lower Tithonian red radiolarian chert is the youngest lithology but is older than the youngest cherts in units to the north.

Yalongmai unit. This unit crops out in two zones, which are separated by a north-south-trending valley. Each zone has a characteristic structural trend and they are assigned to separate subunits c. $2 \mathrm{~km}$ wide. The Chiangdui subunit oceurs as a NESW-oriented strip that structurally overlaps the east-west-trending Baigang subunit. Although lithologies are similar to those in the Maniga unit, they are more intensely sheared and/or foliated. Most (about $80 \%$ ) of the unit is composed of intercalations of differently coloured, pervasively foliated, purplish red or bluish grey varicoloured calcarcous shales. Calciturbidites are common and primary sedimentary structures remain. Sheared varicoloured tuffaceous cherts are purplish red or greenish grey. Locally chert is intercalated with intensely sheared tuffaceous mudstones. Red radiolarian chert similar to that elsewhere throughout the Bainang terrane occurs in several tectonic slices up to $20 \mathrm{~m}$ thick and is less sheared than adjacent lithologies. No identifiable radiolarian fossils were extracted and the intensity of tectonic disruption precludes the confirmation of the lithostratigraphic suecession. Some chert in the southern portion of the unit includes centimetre-thick layers of pink micritic limestone and thinly interbedded chert and limestone laminae indicating that it accumulated at, or just above, the carbonate compensation depth (CCD).
The Yalongmai unit is characterized by repetitions of intensely sheared and foliated tectonic slices composed of different lithologies. Bedding and tectonic layering dip in a manner similar to that seen in other units. Tectonic layering is subparallel to bedding. Shearing patterns are lithologically controlled. Some chert is tectonically dissociated into lenses, asscmblages of which are mappable over several kilometres. Cherts exhibit S C, or phacoidal fabrics and are rarcly foliated whereas foliation in calcarcous shales is typically penetrative. Foliation becomes more pervasive to the SE. Stretching lineation, crenulation and kink bands are also associated with foliation. Lineation is manifested by fine penetrative mineral fibres. Sporadically developed crenulation occurs on some foliation surfaces as small patches of closely spaced wrinkles. Kink bands are more abundant in the SE part of the unit and are locally arranged into swarms of conjugate bands. Stretching lineations are deformed by both crenulation and kink bands. In each subunit they plunge gently to moderatcly to the north and are strongly grouped around mean values of $352^{\circ} / 31^{\circ}$ and $352^{\circ} / 38^{\circ}$ (Fig. 3). Crenulation crests are almost horizontal and their orientations vary from west to SSW with mean values of $244^{\circ} / 05^{\circ}$ and $250^{\circ} / 04^{\circ}$ for each subunit. Kink band axes are oriented WSW and are nearly horizontal with close mean values $255^{\circ} / 05^{\circ}$ and $253^{\circ} / 04^{\circ}$ in both subunits. Orientations of all linear structural elements indicate NNW-SSE transport. Rare secondary fine-scalc asymmetric cleavage associated with crenulation indicates south-directed thrusting. Small-seale $S$ and $Z$ intrafolial folds (more common in the Chiangdui subunit) deform both bedding and tectonic layering. Stretching lincation and crenulation are warped in one of these folds. Morphologies and hinge orientations of the folds indicate south-directed thrusting with components of either sinistral or dextral strike slip.

Renchingang unit. This southernmost and structurally lowermost, $1750 \mathrm{~m}$ wide unit is oriented LNE--WSW, parallel to the Baigang subunit, and is thrust southwards over the Indian terrane. Yellowish grey calcareous shale characterizes the unit. In the north, it contains lenticular fragments of normally graded yellowish grey calcarenites. The unit also incorporates lithologies characteristic of the Yalongmai unit, such as varicoloured calcareous shale and red radiolarian chert, which occur in metre-thick tectonic lenses

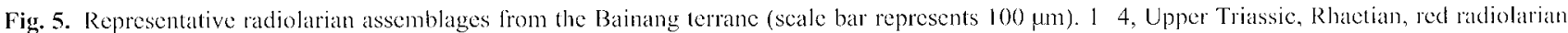
chert, Zongxia unit: I, Livarella sp.; 2, Livarella sp. ef. L. validus Yoshida; 3, 4, Canoptum spp. 5-11, Lower Jurassic, upper Pliensbachian, limestone, Maniga unit: 5, Parahsulm ovale llori \& Yao; 6, Praeconocaryomma immodica Pessagno \& Poisson; 7, Paronaella sp. cf. P. bona (Yeh); 8) Naponasp. cl. N. ceromesanwis Pessagno, Whaten \& Yeh; 9, Broctus ruesi Yeh; 10, Parahsumsp. cf. Lupheriumsp. A sensu Pessagno \& Whalen, 1982; 11 , (anophlm sp. 12-15. Middle Jurassic, upper Aalenian (UAZ95 2), red radiolarian chert, Bangga unit: 12, Ristola(?) praemirifusus Baumgartner \& Barlolini; I3, Hsumsp. cf. II. matsuokai Isozaki \& Matsuda; 14, Transhsumm sp. cf. T. hisuikyoense (Isozaki \& Matsuda); 15, Laxtormm sp. cf. L. jurtsicum Isozaki \& Matsuda. 16-22, Middle Iurassic, Bajocian (UAZ95 3-4), tuffaceous chert, Maniga unit: 16, Dictyomilrella (?) kamoensis Mizulani \& Kido; 7 , Transhsum maxwelli (Pessagno); 18, T. brevicostatum (Ozvoldova); 19, Unuma latusicostatus(Aita); 20, U. typicus Ichikawa \& Yao; 21 , Stichocallsa japonica Yáo; 22, Pavicingula dhimenaensiss.l. Baumgarner. 2325 , Middle Jurassic, uppermost Bajocian to lower Bathonian (UAZ95 5) tulfaceous

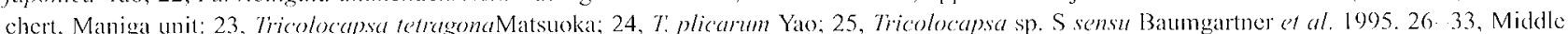
Jurassic, upper Bathonian-lower Callovian (UAZ95 7), tuffaceous chert, Maniga unit, Bainang terrane: 26 , Obesacapsula morroensis Pessigno; 27. Acanthocirats suboblongus (Yao); 28, Palinandromeda podbielensis (Ozvoldova); 29, Mirifusus guadahupensis Pessagno; 30, Selhocapsasp. cf. S. dorvphaeroides (Neviani); 31, Ristolasp). cf. R. altissima altissima (Rüst); 32, Stichocapsa (?) tsumoensis (Aita); 33, Spongocapsula perlmerae Pessagno. 34-39, Upper Jurassic; Tithonian (UAZ95 12), red radiolarian chert, Bangga unit: 34, Dictyomitra minoensis (Mizutani); 35, D. apiarimn (Rüst); 36, Cingulorurris cylindra Kemkin \& Rudenko; 37, Protumumasp. cf. P. japonicus Matsuoka \& Yao; 38, Dicerosatumalis sp. cl. D). dicranacunthos (Squinabol); 39, Hiscocapsasp. ef. H. Iterculus (Parona). 40 44, Upper Jurassic, upper Tithonian to Lower Cretaceous, middle Valanginian (UA795 13 16), red radiolarian chert: 40, Dictyomitra encellens (Tan); 41, Cholanium sp. of. C. puga (Schaaf); 42, Thanarta brouweri (Tan); 43, Syringocapsasp. cf. S. longinhowsud; 44, Parvicingulaboesii (Parona). 45-54, Middle Aptian (U.A. 7) siliccous mudstone, Bangga unit: 45, Pseudodictyomitrasp. cl. P. honnatisima (Squinabol); 46, Dictvomitra conmunis (Squinabol); 47, Torculumsp. cl. T. bastetani O'Dogherty; 48, Xilus chava (Parona); 49, X. spicularias (Aliev); 50, Turbocapsula costala (Wu); 5I, Acaeniolyle umbilicata (Rüst); 52, Godia decora (Li \& Wu); 53, Triacioma hybam Iorenlan; 54 Trisyringiumsp. cf. T. capellinii Vinassa. 
and slices disseminated within calcarcous shale. Chert is thinbedded and includes layers $(1-3 \mathrm{~cm})$ of pink to red micritic limestone as well as fincly laminated chert and limestone, amounting to c. $25 \%$ of the succession. The presence of thin pelagic limestones intercalated with chert indicates sedimentation above or near the CCD.

The southern part of the unit consists of structurally homogeneous shales. To the north, thin slices of different lithologies are tectonically repeated. Penetrative foliation accompanied by stretching lineation characterizes the unit. Abundant kink bands deforming foliation and strctching lincation occur in swarms. Crenulation is rare. Foliation generally dips north (mean $359^{\circ}$ \% $40^{\circ}$ ) with local overturning. Stretching lineations generally dip north (mean $002^{\circ} / 46^{\circ}$ ). Kink band axes are nearly horizontal (mean $262^{\circ} / 04^{\circ}$ ). Linear structural elements indicate north-south transport. Small intrafolial S-shaped folds deform foliation and stretching lineation and indicate sinistral along-strike displacement.

Intrusions. Sills of high-Ti alkaline basalt up to tens of metres thick are abundant in the southern tract. They are particularly abundant in the Maniga unit, where they form up to $50 \%$ of the unit's volume. Baked contacts with host rocks indicate that metamorphism associated with intrusion predates shearing. The sills are structurally disrupted by the same tectonic features that imbricate other elements of the Bainang terrane stratigraphy. They intrude most lithologies, except the youngest red radiolarian cherts. Thus, basic magmatism probably predates deposition of this chert, and is inferred to be pre-Callovian. As the sills have intruded all other lithologies, including upper Aalenian-Bathonian tuffaccous chert, intrusion is constrained to a narrow interval in the late Mid-Jurassic. We note that coeval intraplate basic alkaline magmatism is known from potentially correlative rocks in the Western Ladakh Himalaya (Danclian \& Robertson 1997; Robertson \& Sharp 1998) where Middle Jurassic lavas and volcaniclastic deposits occur in the Karamba Complex, and diabase sills are common in the adjacent Lamayuru Complex.

\section{Synthesis: a model for Neotethys evolution}

Detailed examination of the Bainang terrane elucidates two distinet aspects of Neotethyan evolution: (1) the history of the floor of this occan is preserved in fragments of material that have been accreted into the terrane; (2) consumption of oceanic lithosphere and the nature of subduction-accretion processes at an intra-oceanic subduction system are recorded in the accretionary wedge.

\section{Depositional setting and travel history of accreted material}

The remnant stratigraphy of an occanic plate fragment preserved in an accretionary wedge provides temporal constraints on the travel history of subducted oceanic material and its accretion (Isozaki et al. 1990; Matsuda \& Isozaki 1991). Few remnants of any subduction complexes are well preserved along the length of the suture between India and Asia. Rocks within the Bainang terrane provide constraints on accreted Ncotcthyan oceanic matcrial. They are interpreted in terms of depositional settings and compared with rocks from the modern ocean floor or exposed on land in accretionary wedges. Where the Bainang terranc record is incomplete, correlation with other units described from further west along the suture permits reconstruc- tion of the history of sedimentation upon the now subducted floor of Neotethys.

Northern tract: travel and approach towards a convergent margin. A similar mix of lithologies and stratigraphy occurs in the Bangga and Zongxia units. It therefore scems plausible that they accumulated in close proximity. The oldest rocks are red radiolarian chert, a distinctive oceanic pclagic lithology that is well known from many accretionary wedges preserved on-land (Isozaki et al. 1990; Matsuoka \& Yao 1990; Zyabrev 1996; Kusky \& Bradley 1999) as well as from drilling on the occanic floor in the western Pacific (Matsuoka 1992). This lithology accumulated below the CCD far from the influence of any terrigenous sedimentary input.

Siliceous mudstones contain finc-grained clastic and biogenic components. They are hemipelagic and resemble modern sediments from oceanic swells and outcr trench slope settings (Moore et al. 1982). In ancient accretionary wedges elsewhere, they typically overlie chert sequences and are commonly interpreted to have accumulated upon oceanic crust close to a convergent margin (Matsuoka \& Yao 1990; Matsuda \& Isozaki 1991). Incrcasing proximity to a subduction zone during plate convergence is indicated by the appearance of felsic tuff. Thicker tuff layers are turbidites containing volcanogenic material redeposited from the inner trench slope.

Northern tract stratigraphy indicates deposition in two different sedimentary environments. Initially, sedimentation occurred in an open occan pelagic environment from at least Rhaetian to early Aptian. This was followed by a short interval of hemipelagic sedimentation until the late Aptian. The succession records a long $(100 \mathrm{Ma})$ period of north-directed travel within an open ocean setting towards a convergent margin, the final approach to which is recorded in hemipclagic siliceous mudstones with abundant tuff layers.

Southern tract: thermotectonic subsidence in proximity to India. From Late Triassic to Bathonian time, evolution of the southern tract appears to have differed from that of its northern counterpart. During the Rhactian to late Aalenian, hemipelagic varicoloured mudstone and limestone was deposited north of a source of fine-grained clastic and calcarcous detritus. Micritic limestones indicate periods of low clastic input above the CCD. The late Aalenian until the end of the Bathonian was characterized by basaltic volcanism and the deposition of aquagene tuffs. The absence of carbonates suggests that siliceous pelagic background sedimentation continued below the CCD. Callovian sedimentation was dominantly pelagic with accumulation of radiolarian chert below the CCD continuing until the Oxfordian-early Tithonian. No younger deposits are preserved and the occanic plate stratigraphy is incomplete. The succession records a change from hemipclagic to pelagic deposition apparently accompanied by oceanic floor subsidence below the CCD. This may reflect drowning of the source of carbonate and terrigenous clastic detritus, and/or retreat of a sediment dispersal system. Coincidence of thermotectonic (cooling-induced) subsidence of the adjacent Neotethyan occan floor below the CCD and drowning of the source area allowed pelagic siliceous sedimentation to become dominant. If Mid-Jurassic basaltic magmatism impeded the regional trend of subsidence, it did not leave any sign of such a change in the stratigraphic record, although the possibility of CCD fluctuations cannot be excluded. Elsewhere, lithologics and patterns of magmatism in the southern tract closely resemble those in the Maniga unit but correlation remains tentative without age control. Proximity to a detrital source area located to 
the south is indicated by calciturbidites within varicoloured calcareous mudstones - shales in all three units.

Lithologies, stratigraphy and magmatism in the southern tract compare well with those described from the Karamba Complex in the Ladakh Himalaya, further west along the suture zone. This complex accumulated on a continental rise and contains distal equivalents of continental slope deposits in the Lamayuru Complex (Danelian \& Robcrtson 1997; Robertson \& Sharp 1998). These complexes are in turn distal equivalents of the Zanskar shelf succession on the Indian passive margin. The uppermost Triassic-Lower Jurassic Karamba Complex is mudstone-dominated, and possesses pelagic limestone and calciturbiditcs with basic volcaniclastic rocks and within-plate basalts in the Middle Jurassic range. Reduction of clastic input and subsidence below the CCD occurred during the Jurassic (Robertson \& Sharp 1998). In the Late Cretaccous the Karamba and Lamayuru complexes were thrust southwestwards over the Zanskar shelf (Scarle et al. 1988; Robertson \& Sharp 1998). Santonian chert (Danelian \& Robertson 1997) and Campanian pelagic carbonate (Robcrtson \& Sharp 1998) constrain emplacement to the post-Campanian. Comparison with the Karamba Complex supports interpretation that the southern tract accumulated in close proximity to the northernmost edge of India.

Although the oldest sedimentary rocks in the Bainang terrane are Upper Triassic, by the time they were deposited, Tethys, which had opened in the Permian, was a relatively wide ocean with a well-established area of pelagic sedimentation (Stampfii \& Borel 2002). This is documented in red ribbon-bedded cherts of the northern tract, which were deposited below the CCD. No fragments of Permian to Mid-Triassic, Jurassic or Cretaceous occanic crust can be easily recognized. Whether it never existed, was tectonically eroded off frontal parts of the wedge, or was overridden during collision (c.g. Boutelier et al. 2003) is unccrtain.

Deposition of sedimentary sucecssions in the two Bainang terrane tracts appears to have geographically separated locations within Tethys. A simple explanation is that the two tracts were separated by an oceanic spreading ridge (Fig. 6). Detritus shed into the southern tract from the northern margin of the Indian subcontinent constrains its position. Progressively younger sections of oceanic crust should have lain north of it towards the ridge (Stampfli \& Borcl 2002). Therefore, Upper Triassic oceanic cherts in the northern tract probably developed north of the ridge and travelled further northwards during the Jurassic whereas the southern tract remained under the influenec of sediment derived from the northern margin of continental India.

Temporal constraints on ocean-floor evolution. A remarkable change in the course of evolution of the Neotethys occurred by the beginning of the Late Jurassic. Subduction of Ncotethyan oceanic lithosphere began, possibly resulting from reorganization of plate boundaries in response to events elsewhere in Tethys. It occurred both along the southern margin of Eurasia and at an equatorially located subduction system within Tethys. Intraoceanic subduction at a south-facing intra-Neotethyan subduction system was associated with late Mid-Jurassic-Early Cretaceous volcanism in the Zedong terrane (McDermid et al. 2001, 2002; McDermid 2002) whereas continental margin subduction bencath Eurasia was associated with Late Jurassic-Early Cretaccous Sangri Group volcanism in the Lhasa terrane and later magmatism associated with the Gangdese belt (Badengzhu 1979).

In the Mid-Jurassic (pre-Callovian time) volcaniclastic sedimentation and intrusion of basic alkaline sills was widespread in the southern tract. This magmatism may have been a precursor to break-up and eventual development of the Argo abyssal plain off NW Australia, where the oldest oceanic crust is 163 Ma (Callovian-Oxfordian; Sager et al. 1992). Rifting within castern Neotethys occurred north of India and propagated southward, leading to separation of India from Gondwana and opening of the Indian Ocean (von Rad et al. 1992). A change in background sedimentation probably occurred in response to cooling-induced subsidence of Neotethyan lithosphere below the CCD and drowning of the source area. Mid-Jurassic drowning of the northern Indian shelf further indicates this thermotectonic subsidence.

In accreted sedimentary sections the boundary between pelagic and hemipelagic deposits typically records the time of approach towards a subduction zone. The transition between hemipelagic and trench-fill deposits marks the arrival of oceanic lithosphere at a trench immediately prior to its accretion (lsoraki et al. 1990). If trench-fill turbidites are not preserved the age of the youngest hemipelagic material provides a maximum constraint on the timing of accretion.

An almost complete stratigraphy is preserved in the northern tract of the Bainang terrane. The change from pelagic chert to hemipelagic siliceous mudstone accumulation records the initial influcnce of subduction zone-related sedimentation. The oldest hemipelagic siliceous mudstone in the northern tract provides the best approximation of the timing of this latest carly Aptian (midCretaceous) event. As trench-fill turbidites are absent, the age of the youngest siliceous mudstones (early late Aptian) is the maximum constraint on the timing of accretion into the wedge. Detailed radiolarian studies provide age control on the progressive younging of accreted units in other subduction complexes studied elsewhere (Matsuoka \& Yao 1990). Iowever, this is discernible on a scale of tens of kilometres, which is greater than the total width of exposure of the Bainang terrane. Nevertheless, radiolarian biostratigraphy indicates coeval accretion of Bangga and Zongxia units.

The upper portion of the oceanic plate stratigraphy in the southern tract was probably off-scrapped, and, as it is not prescrved, no temporal constraint on accretion can be determined. As this tract originated eloser to the Indian subcontinent it should have been to the south of units accreted earlier, suggesting that aceretion of the southern tract probably followed that of its northern counterpart. A more complete stratigraphic section has been described from along strike in NW India within the correlative Karamba Complex, which contains a similar sequence with few turbidites that developed in front of the intraoceanic Spontang are (Corficld et al. 2001). Studies of these rocks have indicated that pelagic sedimentation may have persisted there until the Campanian (Robertson \& Sharp 1998). If the Bainang terrane is similar and the southern tract also accreted in post-Campanian time, then an overall trenchwardyounging succession of landward-dipping slices is preserved actoss the terrane and a significant temporal gap exists between the accretion of northern and southern tracts.

\section{Subduction-accretion}

Bainang terrane units that accumulated in different parts of Neotethys are now juxtaposed within a $10 \mathrm{~km}$ wide imbricate thrust stack. Oceanic pelagic (cherts, micritic limestones) and hemipelagic (mudstones, siliccous and calcarcous mudstones) lithologics dominate. The most likely explanation for assembly of various oceanic lithologies in such a complex is subductionrelated accretion. The overall structure of the terrane represents an imbricate thrust stack of multiple north-younging, south- 


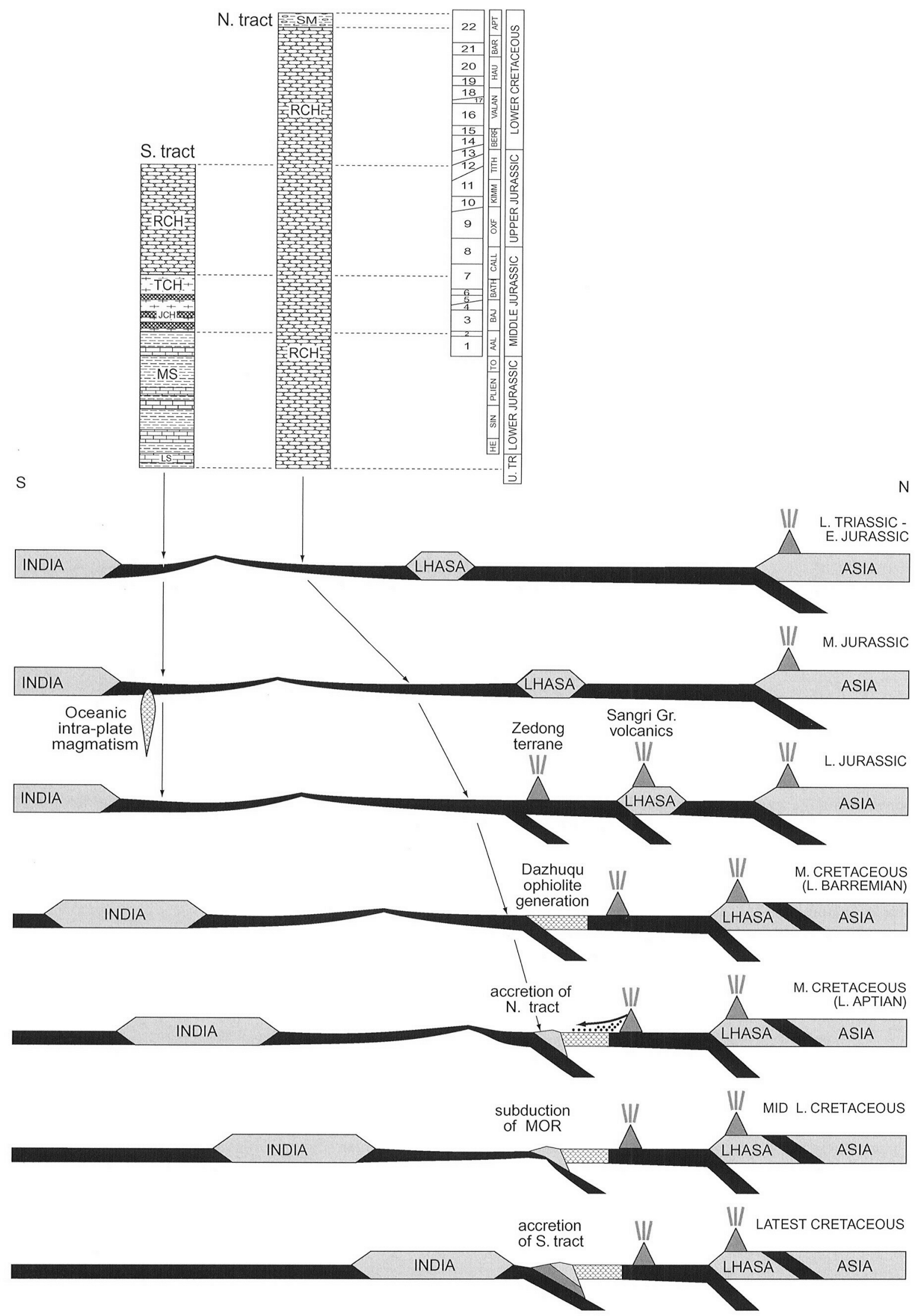

Fig. 6. Interpretation of oceanic plate stratigraphies in the Bainang terrane, southern Tibet, and updated evolutionary scenario for the closure of the Tethys. Jurassic subduction underneath Asia is shown after Allègre et al. (1984) and Van der Voo et al. (1999). The mid-Late Cretaceous subduction of a mid-ocean ridge (MOR) may involve either an active or a fossil spreading ridge. Intra-oceanic subduction system is shown after Aitchison et al. (2000). 
verging tectonic slices. Structural and stratigraphic aspects of the Bainang terrane point to assembly in a subduction zone with major tectonostratigraphic pattcrns and partially preserved oceanic plate stratigraphics comparable with those observed in modern and aneient accretionary wedges. Fabrics within the terrane are similar to those described from accretionary complexes clscwhere (e.g. Alaska; Kusky et al. 1997; Kusky \& Bradley 1999). Small-scale intrafolial folds and large thrustrelated isoclinal folds, stretching lineations, crenulation and kink bands together with other kinematic criteria from shear zones such as phacoidal and S-C fabrics indicate overall south-directed thrusting.

Structural styles vary progressively across the terrane, with a SSE increase of shear intensity from higher to lower structural levels indicating different depths of deformation and probably reflecting vertical growth rather than lateral accretion. It is widely accepted that accretion may occur in two modes: (1) offscrapping at the toe of an accretionary wedge; (2) underplating at deeper levels (Silver et al. 1985; Moore \& Silver 1987; Isozaki et al. 1990; Kimura \& Ludden 1995; Kusky et al. 1997). Although no diagnostic criteria for uncquivocal discrimination between these two modes exist, some inferences as to the mode of accretion within the Bainang terrane can be made through analysis of structural styles and the nature of the preserved oceanic plate stratigraphics. Important temporal constraints can be extracted to determine the approximate timing of Bainang accretion events. The absence of décollement-related mélanges and trench-fill turbidites complicates interpretation of the mode and time of accretion.

The structural style and stratigraphy preserved in the Bangga unit do not permit casy discrimination of the mode of accretion. It may represent the off-scrapped portion of the accretionary wedge. Off-scrapping of pelagic--hemipelagic sections on the incoming occanic platc occurs at the Barbados Ridge accretionary wedge, where no trench-fill sediments are present (Moore et al. 1995). The relatively simple structure exhibited within this unit might have originated by off-scrapping numerous thin (hundreds of of metres) slices. Their extent is comparable with the zone of initial accretion in modern accretionary wedges (Brown et al. 1990; Moore et al. 1995). Later shear zones that cut these slices may be out-of-sequence thrusts that developed in the zone of subsequent thickening (Brown et al. 1990; Moore et al. 1995) but the density of biostratigraphic data is insufficient to test this hypothesis. Turbidites, which might be expected as trench-fill sediments above more distal siliceous mudstones, are rare, suggesting they may have been off-scraped at higher levels of the accretionary wedge with the chert-siliceous mudstone sections being underplated later. Some clastic-dominated zones of turbidites that occur in the region (Aitchison et al. 2000) may represent such material. If the Bangga unit was underplated, the absence of extensive décollement-related shearing may be explained by down-stepping versus gradual propagation through thickening of the décollement (Moore \& Byrne 1987).

The Zongxia unit appears to better fit the mode of underplating, rather than off-scrapping. Numerous tectonic slices of coeval siliccous mudstones occur within a unit $>1 \mathrm{~km}$ thick. The tectonic 5-20 $\mathrm{m}$ thick slices are comparable with those in other on-land accretionary wedges (Matsuoka \& Yao 1990; Matsuda \& Isozaki 1991). The nature of the acereted slices and the degree of shortening are inconsistent with the types of structures observed in the zone of initial accretion in modern accretionary wedges where off-serapping occurs. The unit is thus inferred to have becn underplated immediately underneath the Bangga unit, as both probably accumulated in relative proximity. Shearing occurs in seattered zones and is locally more penetrative, suggesting both down-stepping and gradual downward propagaltion (through thickening) of the décollement during accretion. Tectonic lenses of chert represent fragments of the original stratigraphic section that underlay the mudstones. The cherts are considerably older than adjacent mudstones and depositional transitions between these lithologies were not observed. 'Thus, they were probably juxtaposed during out-of-secuence thrusting or duplexing.

Intense shearing, with development of metre-scale lenses and phacoidal and S-C fabries in the Maniga unit, is interpreted to be décollement related. Together with the absence of upper levels of the expected stratigraphic section, this is consistent with underthrusting and underplating. Shear patterns point towards possible shear zone thickening and gradual downward propagaltion of the décollement. A downward increase in the intensity of shearing may indicate a longer pathway along the decollement with a progressive increase in the depth of deformation. Out-ofsequence duplexing similar to that recognized in the Shimanto terrane, SW Japan (Hashimoto \& Kimura 1999) is the most probable mechanism through which underplating occurred. Lithological differences with the Zongxia unit suggest considerable original separation between depositional sites.

Underplating by duplexing of sheared sections is also inferred for the Yalongmai and Renchingang units. The development of penetrative foliation and stretching lineation reflects décollement-related deformation at greater depths than for the Maniga unit. Gradual downward propagation of the decollement through thickening of the associated shear zone probably occurred during underplating. The disposition of these three neighbouring units probably corresponds to their original relations in the growing accretionary wedge.

It is likely that many of the distinctive features the Bainang terrane displays are intrinsic to development in an intra-oceanic subduction setting and not merely artefacts of fragmentary preservation. The absence of trench-fill turbidites appears to be an inherent feature of the Bainang terrane. Aceretionary wedges associated with continental convergent margins typically are dominated by voluminous arc-derived trench-fill turbidites (Dickinson \& Seely 1979) although rare exceptions exist, both on-land (Zyabrev 1996) and offshore (Moore el al. 1995). As many underplated sections of other accretionary wedges contain such turbidites it seems unlikely that Bainang terrane turbidites were removed by off-scraping. Unless forcare basin growth was prodigious, entrapment of arc-derived volcanic detritus can also be ruled out, as the foreare region would have been over-topped. The Barbados Ridge region is the only modern accretionary wedge studied by Occan Drilling Program drilling in an intraoccanic island are where pelagic and hemipelagie sediments are being delivered on a subducting plate (Moore et al. 1995). Despite the occanic setting, the incoming Atlantic Plate carries significant sedimentary and biogenic influxes derived from nearby South America (Mascle \& Shipboard Scientific Parly 1988; Moore et al. 1995). Although most accreted sedimentary sections are terrigenous, the locally sourced sediment influx at the deformation front and within the wedge is minimal. Older on-land portions of this wedge also appear to contain scant volcanogenic material (Westbrook 1982). In an intra-oceanic are setting, where there is limited detrital sediment supply from a chain of widely spaced and largely submerged voleanoes, it scems likely that the trench might be starved of sediment.

The development of mélanges is widely regarded as a hallmark of subduction--.accretion complexes (Dickinson \& Seely 1979; Kusky \& Bradley 1999). This can be related to shearing 
along the décollement during underthrusting (Moore \& Byrne 1987; Hashimoto \& Kimura 1999; Kusky \& Bradley 1999) or to mud diapirism (Orange 1990). Despite widespread structural disruption, the Bainang terrane is devoid of extensive zones of classic block-in-matrix mélange. We suggest that because the upper portion of underthrust sections lacked any thick, watersaturated clastic deposits this did not favour the formation of mélanges. As the sedimentary veneer upon subducting Neotethyan lithospherc was thin, this probably predetermined shear strain distribution, resulting in the development of thin tectonic slices (Kusky et al. 1997) in the imbricate thrust stack. Out-ofsequence thrusting and duplexing further accentuated the already thin-skinned imbrication. Elements of the structure within the Bainang terrane exhibit characteristics of duplexes and the entire terrane might be described as a complex imbricate duplex thrust system.

Although some structural overprinting and tectonic telescoping within the Bainang terranc might have occurred during the arccontinent and later continent-continent collisions, little cvidence for this is scen. Despite its position within the Yarlung-Tsangpo suture zone, only the faults that bound the terrane and rare strike-slip faults cutting the terranc are clearly related to collision. As shearing, folding and associated small-scale fabrics described hercin are restricted to the Bainang terrane we interpret these features as products of compound diachronous deformation during accretion, rather than a complex polyphase history.

When the Indian passive margin arrived at the subduction zone, deformation affected the continental risc. Southward progradation of thrusting resulted in the development of a regional imbricate thrust stack. Early deformation within the Indian passive margin has been interpreted as syncollisional stacking, and was accompanied by low-grade metamorphism dated at around $50 \mathrm{Ma}$ (Burg 1983; Burg \& Chen 1984; Burg et al. 1987; Ratschbacher et al. 1994). The only post-accretionary features mapped within the Bainang terrane are NNW-SSEtrending cross-faults that cut the terrane. As these faults do not cxtend across adjacent terranes they are inferred to have developed prior to terrane bounding faults.

Distinetly dissimilar sedimentary histories are recorded by the northern and southern tracts of the Bainang terranc, which arc most simply interpreted as having developed in separate arcas within Tethys. As differences in structural styles preclude the interpretation that these two tracts are juxtaposed along an outof-sequence thrust, it seems probable that the northern tract developed to the north of its southern counterpart and was the first to be accreted into the terrane. Existing models for the northward transit of India and consumption of Neotethyan lithosphere along the southern margin of Asia suggest that convergence was approximately trench-normal. The Bainang terrane, however, did not develop in association with this particular convergent (continental margin) plate boundary. Its development was instead associated with a south-facing intra-oceanic subduction system within Neotethys. The orientation of this plate boundary is not particularly well constrained, but magnetic data from voleanic rocks that developed above the subduction zone indicate that portions prescrved in central Tibet developed at near equatorial latitudes (Abrajevitch et al. 2001).

The carliest subduction-related accretion in the Bainang terrane closely post-dates suprasubduction zone generation of ophiolite in the Dazhuqu terrane (Ziabrev 2001; Ziabrev et al. 2003). Biostratigraphic data indicate that the northern tract had been accreted by the end of the Aptian. The youngest hemipclagic deposits, especially those in the Zongxia unit, include abundant felsic tuff layers indicating that related volcanic arc activity persisted until at least the late Aptian. The rest of the Bainang terrane was accreted some time later, with the three units of the southern tract being consecutively underplated. By correlation with the Karamba Complex in NW India, we infer post-Campanian accretion prior to arrival of Indian continental crust at the subduction zone.

Although fragmentary preservation of terranes characterizes many collision zoncs, there appears to be a temporal gap betwecn the two episodes of accretion. Seismic tomography suggests continuous, rather than episodic, subduction of a single slab of occanic lithosphere beneath the intra-Neotethyan oceanic island are (Van der Voo et al. 1999). Thus, some explanation must be sought for the gap between accretion events. Rare, isolated blocks of foliated garnet-bearing amphibolite in serpentinite mélange at the base of the Dazhuqu terrane ophiolitic suite, as well as mylonitic peridotites (base of the West Dazhuqu massif), have been interpreted to indicate early intra-oceanic southward thrusting (Girardeau et al. 1984). The amphibolites have been dated using $\mathrm{Ar} / \mathrm{Ar}$ methods (84 Ma; Wang et al. 1987) and development of such rocks has traditionally been interpreted as an indicator of when an ophiolite is emplaced onto a continental margin. However, it has recently been suggested that analogous high-temperature metamorphic rocks associated with Tethyan ophiolites potentially reflect the subduction of a midocean ridge rather than emplacement (Shervais 2001). If so, this could explain the presence of two distinct tracts of accreted material within the Bainang terrane. However, other potential indicators of ridge subduction such as near-trench magmatism have not been reported from the region. Some of the intervening frontal portions of the Bainang terrane that had been accreted by the time of a ridge subduction event may have been tectonically croded. Accretion of now oceanic fragments resumed only after subduction of buoyant segments of the mid-ocean ridge. Underplating of the southern tract units was rapidly followed by collision with the Indian subcontinent. Collision of the intraoccanic island arc system, comprising the Bainang, Dazhuqu and Zedong terranes, and its emplacement onto the Indian passive margin occurred during the Palcocene (Aitchison ef al. 2000; Davis et al. 2002). Further removal of the rock record may have occurred then and we note that recent models for arc-continent collision suggest that the preservation potential of arc, forearc and subduction complexes during such events is not high (Chemenda et al. 2001; Boutelier et al. 2003). Together, the units, which accreted to India, travelled northwards as passengers to witness and participate in the final India-Eurasia collision.

We thank members of the Tibetan Gcological Survey (Team No. 2) and Tibetan Geological Society, whose efforts have helped to make this research possible. Many of these fricnds have assisted with arranging logistics and permission. Many villagers also helped and made life in the field more comfortable. We appreciate suggestions of 13. S. Carter on identification of some Triassic radiolarians. Reviews by P. Kapp, T. Kusky and Y. Dilek helped to improve the manuscript. This work was supported by grants (to J.C.A.) from the Research Grants Council of the Hong Kong Special Administrative Region, China (Project Nos. HKU7102/98P, HKU 7299/99P and HKU 7069/01 P)

\section{References}

Abrajevitch, A., Aitohison, J.C. \& Al.I, J.R. 2001. Paleomagnetism of the Dazhugu Terrane, Yarlung Zangbo Suture Zone, Southern Tibet. EOS transactions, American Geophysical Union tall Meeling Stuplement, GPl1A0188

AITCHISON J.C., BADINGZZIU \& DAvis, A.M. ET AL. 2000. Remnants of Cretaceous intra-oceanic subduction system within the Yarlung-Zangbo suture (southern Tibct). Earth and Planetary Science Letters, 183, 231-244. 


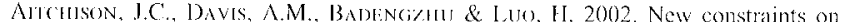
the Indiat-Asia collision: the Lower Miocene (iangrinboche conglomerates. Yarlung Tsangpo suture yone, Sli Tibel. Journal of Asian Larth Sciencer, 21. 253265

Altchison. J.C., DAvIS, A.M. \& AIJ, J.R. IT, M. 2004. Stratigraphic and sedimentological constraints on the age and tectonic evolution of the Neolethyan ophiolites along the Yarlung Tsiangpo suture zone, Tibet. In

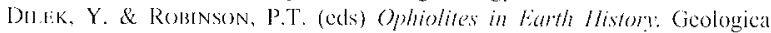
Society, London, Special P'ublications, 218, 147 16164.

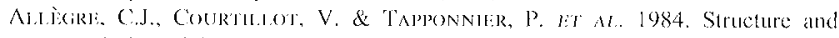
cvolution of the Himalaya-Tibel orogenic belt. Nafure, 307, 1722.

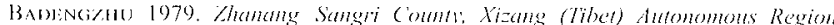
1:50090) Geological Recomatissance Matp. Bureau of Geology and Mineral Resources of Xizang Autonomous Region (jeological Team No. 2 Regional Gological Report, 10.1-88.

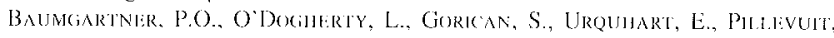

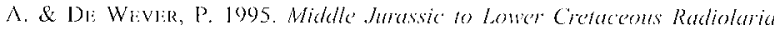

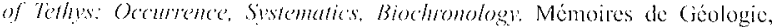
Université de Iálusanne, 23.

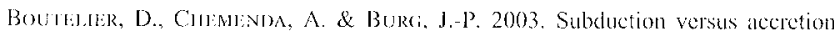
of intra-oceanic voleanic ares: insight from thermo-mechanical antalogue experiments. Euth and Planctury Science letters, 212, 3[--45.

Brown, K.M., MAscili, A. \& Bl:HrmanN, J.II. 1990. Mechanisms of accretion and subsequent thickening in the Barbaldos Ridge aecretionary complex; balanced

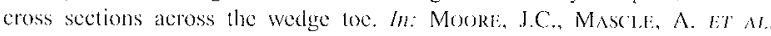

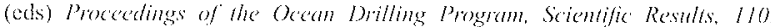
Ocean Drilling Program, College Station, TX, 209-227.

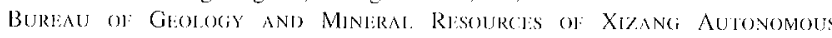
Re(iolon 1993. Regienal Geology of Xizang Tibet) Altomomons Region (icological Publishing House, Beijing

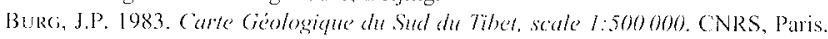

BURci, J.P. \& CHI:N, G.M. 1984. Tectonics and structural zonation of southern Tibet, Chinat. Noutur, 311, 219-223.

Berci, J.P., Lliyri:1oup, A., Girariminu, J. \& Chin, G.M. 1987. Structure and metamorphism of at tectonically thickened continental crust; the Yalu Tsangpo suture rone (Tibet). Phitosophical Transactions of the Roval Society of Lomdon, Serrices A, 321, 67-86.

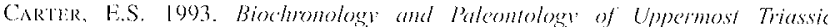

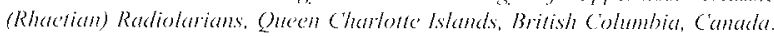
Mémoires de Géologie, Université de Lilusanne, 11

Cartik. L.S., CAmeron, B.F.B. \& Smithi, P.I. 1988. Lower and Middle Jurassic radiolartan biostratigraphy and systematic paleontology, Quecon Charlotte Islands, British Columbial. Cieological Sitrve') of Camada, Bulletin, 386, 1. $10 \%$.

Chliminda, A.I., Yangi, R.K., StIiphan, J.F, Konstantingskaya, E.A. \& IYANGV, G.M. 2001. New results from physical modelling of are-continent collision in Taiwan: evolutionary model. Tectomophesices, 333, 159..178.

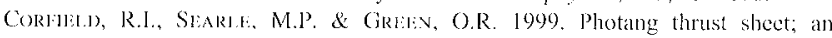
accretionary complex structurally below the Spontang Ophiolite constraining timing and tectomic environment of ophiolite obduction, Ladakh Ilimalaya NW Indial. Joumat of the Geological Society, London, 156, 1031-1044.

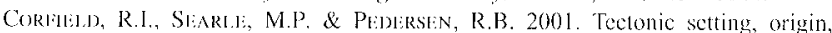
and obduction history of the Spontang Ophiolite, Ladiakh Ilimaliya, NW Indial. fournal of Geology; 109, 715736 .

DANitian, T. \& Robektoon, A.H.F. 1997. Radiolarian evidence for the stratigraphy and palien-oceanography of the deep-water passive margin of the Indian Plate (Karlambal Formation, Indus suture zone, Ladakh Himalaya) Matine Micropaterontology? 30, 171195.

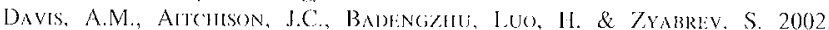
Palcogene island are collision-related conglomerates. Yarlung - Tsingpo suture zone, 'Tibet. Sedimentary' Gerologi: 150, 247.273.

Dickinson. W.R. \& Stiti, D.R. 1979. Strueture and stratigraphy of foreare regions. AAPG Bulletin, 63, 2-31.

Dürre, S.B. 1990. Provenance of Xigaze fore-are basin clastic rocks (Cretaceous, South Tibet). Geolegical Sociefs of America Bullerin, 108,669684

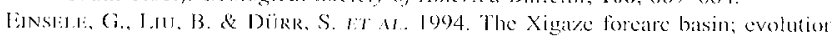
and facies architecture (Cretaceons, Tibet). Sedimentary Geolog:) 90, 1-32.

Gantani, M. \& Gakranti, E. 1991. Multicyelie history of the northern India contincental margin (Northwestern I limalaya). AAPC Bulletin, 75, 1427-1446.

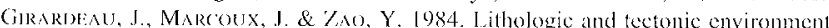
of the Xigaze ophiolite (Yarlung Zanglo sulure zone, southern Tibet, (hina), and kincmatics of its emplacement. Eetogare Geologicae Helvetiace, 77, $153 \cdot(70$.

Girardiau, J., Mercil:R, J.C.C. \& Zaro, Y.(j. 1985a. Structure of the Xigare Ophiolite, Yarlung Zangbo suture yonc. southern Tibet, China; genetic implications. Fectenics, 4, 267.788.

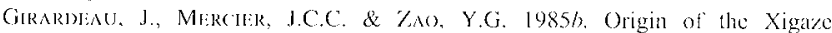
Ophiolite. Yartung Zangbo suture zone, southern Tibet. Tectonophlysics, 119 ,
407433.

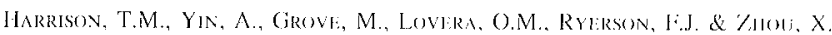
2000). The Zedong Windew: a record of superposed 'Tertiary convergence in

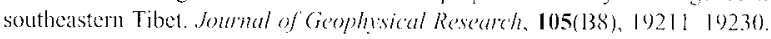

Hashimotor), Y. \& Kintika, G. 1999. Underplating process fron melange formation to duplexing: example fiom the (retatecous Shiminnto Bell. Kii Perinisulia, southwest Japun. Fectonicis, 18, 92107.

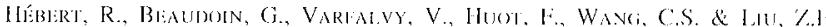
2000. Yarlung Zanglo ophiolites, southern Jibel revisited. In: WAN. X.Q

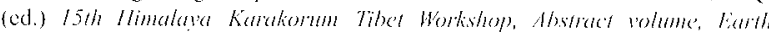
Scichece fromieres, 7. Chenerdu, (hina, 124126.

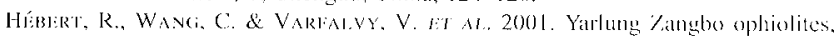
southem Tibet revisited. III: Graslmavn, B. \& Srulwi, K. (eds) Specrial

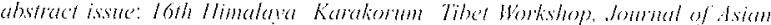
Earth Sciences, 19/3A. 27.28.

HORI, R. 1990. Lower Jurassic Radiolartian Zones of SW Japan. Transuntions and

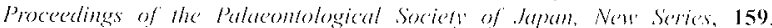
562586 .

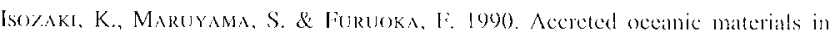
Japan. Fectomophesies. 181, 179205.

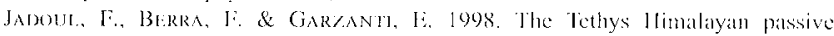
margin from Late Triassic to lanly (retaceous (South Tibut). Jourmal of Asian Eirth Scionces, 16, 173,194.

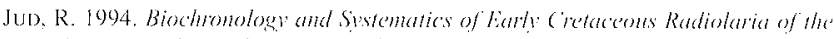

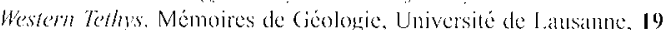

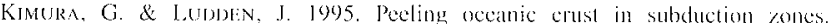
Geolog: 23, 217-220.

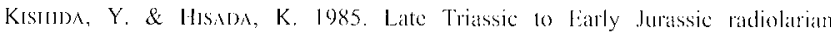
assembliges from the Ueno-mula allea, Kanto Mountiins, central falpan. Memoins of Oscaka Kyoiku Universily; Sories III. 34, 103 129.

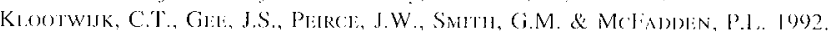
An early India $\Lambda$ sia contact; palcomagnetic constraints from Ninctyeast Ridge, ODP Lcg 121; with Supplementary Dallal 92-15. (reolegy! 20). 395.398 .

KuskY, T.M. \& Bradur.Y, D.C. 1999. Kincmalic analysis ol' mélange fibric: examples and applicalions from the Mellugh Complex. Kenai P'eninsulia, Alaska. fournal of Simctiral Ceology: 21, 1773 1790,

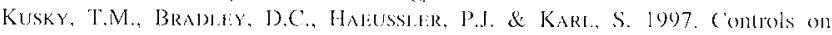
accretion of flysch and mélange bedts an convergent margins: evidence from the Chugach Bay thrust and leeworm mélange, (hugacla aceretionary wedge. Alakka. Tectomics, 16.855878.

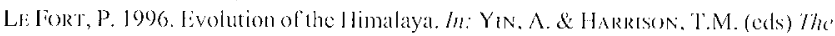
Tectonic Evolution of Asia. Cambridge University Press, New York, 15106.

LuW, G. \& Linstile, G. 1994. Sedimentary history of the Tedhyall basin in the Tibetan I limalayas. Geologiss he Rumlisc/um, 83, 32 61.

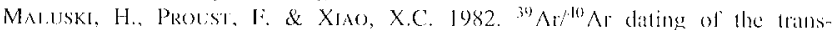
Himaliyan cale-alkaline magmatism of southern Tibet. Noture, 298. $152 \quad 154$.

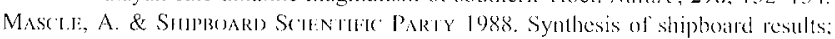
Ley 1 I0 transect of the norihern Barbados Ridge. In: Masc 1,1. A. Merokl.

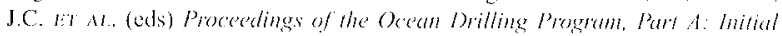
Reports 1/0. Ocean Drilling Program, College Station, T'X, 577.591 .

Matsuoka, A. 1992. Jurassie and Early ('retaceous radiolarians fiom l.eg 129. Sites 800 and 801, westem Pacific Ocean, In: LaRson, R.L. \& I, Anc'Btor, Y.

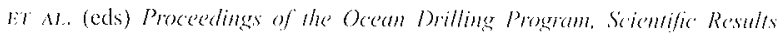
129. Ocean Drilling Program, ('ollege Station, TX, 203220.

MATSUDA, T. \& Iş\%akI. Y. 1991. Well-documented travel history of Mesoroic pelagic chert in Japan; firm remote occion to subduction zone. Textomic's, $10(2), 475499$.

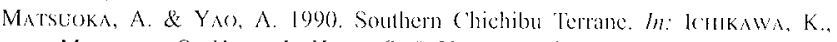

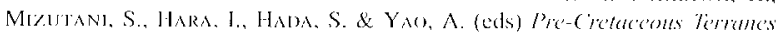
of Japan. Publicenton of KGCT Projed No. 224: Pres-Jurassic livelution of Eastern Asut. ICiCP, Osaka, 203216.

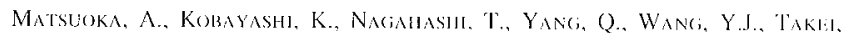
M. \& Zl:Vki, Q.G. 200). Lially Middle Juriassic (Aalenian) radiolarian fitunit from the Xialu chert in the Yardung Zanglo Suture Zone, southern Tibet. In:

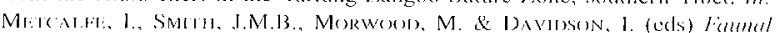

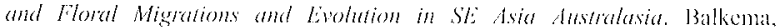
Rotterdam, 105 110.

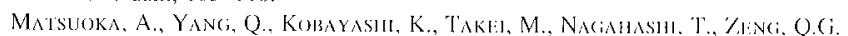
\& WANki, Y.J. 2002. Jutassic (retaceons radiolarian biostratigraphy and sedimentary environments of the Ceno-Tethys: records fiom the Xialu chert

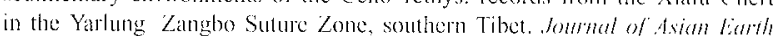
Scicices, 20(3). 277.287.

Ma'DrRma1, I. R. C. 2002. Zethmy tertane, south Thet. Phi) thesis, University of Hong Kong.

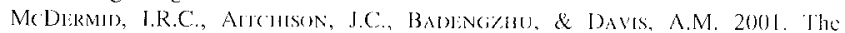
Zedong Terranc: an intra-oceanic magmatic arc assemblige. In: (iRAst:MANN.

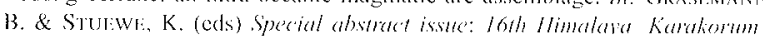


Tibet Workshop, Journat of Asian Earth Sicences, 19/3A, 44

MCDIRMID, I.R.C. AITCIISON, J.C., DAvis, A.M., HARrison, T.M. \& GROVI. M. 2002. The Zedong terrane: a Late Jurassic intra-oceanic magmatic arc within the Yarlung--Zangbo suture zone, southeastern Tibet. Chemical Geologr, $187(3-4), 267-277$.

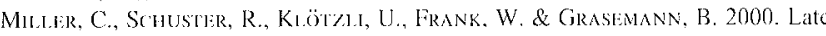
Cretaccous-Tertiary magmatic and tectonic events in the Transhimalaya batholith (Kailas area, SW Tibet). Schneizerische Mineralogische and Pentographische Mitteilungen, 80, 1-20.

Monre G.l. Zhao, Z. Shuplay, T.Il., Bangis, N. \& Moorli, J.C. 1995. Structural setting of the Leg 156 area, northern Barbados Ridge accretionary prism. In

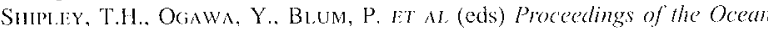
Drilling Program. Part A: Initial Reports, 156. Occan Drilling Program, College Station, TX, 13-27.

Moork:, J.C. \& BYRNI; T. 1987. Thickening of fault zones: a mechanism of mélange fomation in accreting sediments. Geolog; 15, 1040-1043.

Mookri, J.C. \& Sil.vilk, E.A. 1987. Continental margin tectonies: submarine inceretionaly prisms. Reviews of Geophlsics, 25, 1305-1312

Mocre: J.C.. WATKINS, J.S. \& MCMIIIIIN. K.J. IT A. 1982. Facies belt of the Middle America trench and foreare region, southern Mexico: results from Leg 66 DSDP. In: LEGGi:TT, J.K. (ed.) Trench Forear Geology: Sedimentation and Teatonics of Modem and Ancient Active Plate Margins. Geological Society, London, Special Publications, 10, 77-94.

Murpiy, M.A., YiN, A. \& Harrison. T.M. FT A.. 1997. Did the Indo-Asian collision alone create the Tibetan plateau? Geology, 25, 719-722.

Nicolas, A., GlRardiau, J. \& Marcoux, J. rT a.. 1981. The Xigaze ophiolite (Tibet); a peculiar oceanic lithosphere. Nature, 294, 414417.

O'Dogirisix'Y. I. 1994. Biodmonolegy and palesnology of Mid-Credaceous. radiolarians from Northern Apennines (haly) and Betic Corlillere (Spain). Mémoires de Géologie, Université de Lausanne, 21.

Orange: D.L. 1990. Criteria helpful in recognizing shcar zone and diapiric melanges: example from the Iloh aceretionary complex, Olympic Peninsula, Washington. Geological Suciery of America Bulletim, 102, 935-951.

PEArce, J.A. \& Mj:I, H. 1988. Volcanic rocks of the Tibet Geotraverse: Lhasa to Colmud. Report of the Royal Society-Acadenia Sinica geotaverse of the Qinghai-Xizang Platcau. Philosophical Tramsactions of the Roval Society of Londen, Sories A, 327, 215238

Pissngino, E.A. \& Whales, P. 1982. Lower and Middle Jurassic Radiolaria (multicyrtid Nassclariina) from California, cast-central Oregon and the Queen Charlotte Islands, 13. COे Micropaleontology, 28, 111-169.

Proust, F., Burg, J.P., Matte, P., Thaponniler, P., Li, T., Li, G. \& Chen, G 1984. Succession des phases de plissement sur une transversale du Tibe méridional, implication geodynamiques. In: Mercier, J.L. \& GUangelen, L. (cds) Mission Fanco-Chinoise an Tibu 1980. Etude géologique et géophysi-

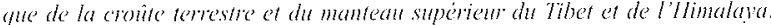
CNRS, PaIT, 385- 392.

RATSCHBACHiR, I., Firisch, W. \& Liu, G. 1994. Distributed deformation in southern and western Tibet during and alter the India-Asia collision. Jounat of Geophwical Researh, 99, 19917-19945.

Robiz'Tson. A.H.F. \& SHARP, I. 1998. Mesozoic deep-water slope rise sedimentation and volcanism along the North Indian passive margin: evidence from the Karamba Complex, Indus suture zone (western Ladakh I limalaya). Jounal of Asian liarth Sciences, 16, 195215

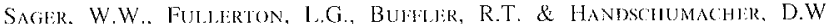
1992. Argo abyssal plain magnetic lincations revisited; implications for the onset of seafloor spreading and tectonic cvolution of the Eastern Indian Ocein. In: Gradsitin, F.M. LudDIin, J.N. IET M. (eds) Proceedings of the Ocean Drilling Program, Scienific Resulss, 123. Ocean Drilling Program, Cotlege Station, TX, 659-669

SEARIF, M.P. WINDLley, B.F, \& Coward, M.P. IT Al. 1987. The closing of Tethys and the tectonics of the Himalaya. Geological Society of America Bullein. 98, 678.701

Sisarle, M.P. CoOplir. D.W.J. \& REx, A.J. 1988. Collision tectonics of the Ladakh-Zanskar Hinalaya. Philosophical Transactions of the Roval Socien of London, Series A, 326, 117-150.

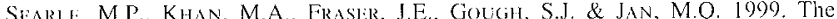

tectonic cvolution of the Kohistan-Karakoram collision belt along the Karakoram Highway transect, north Pakistan. Tectonics, 18, 929-949.

SIIACKI.JYON, R.M. 1981. Structure of southern Tibet; report on a traverse from Lhasa to Khatmandu organised by Academia Sinica. Jownal of Stractural Geology, 3, 97--105.

Sur:Rvals, J. W. 2001. Birth, death, and resurrection: the life cycle of suprasubduction zone ophiolites. Geochemistry, Geophwsics, Geoswstems, 2, Paper number $20006 \mathrm{CO} 00080$.

Siluger, E.A., Elitis, M.J., Britin, N.A. \& Shipl.Fy, T.H. 1985. Comments on growth of accretionary wedges. Geology, 13, 6-9.

STypel, G.M \& Boret. G.D. 2002. A plate tectonic model for the Palcozoic and Mesozoic constrained by dynamic plate boundaries and restored synthetic: oceanic isochrons. Earth and Planetary Science Letters, 196(1-2), 17-33.

Van teer Voo, R., Spakman, W. \& Buiwanid), H. 1999. Tethyan subducted slabs under India. Earth and Planetary Science Letters, 171, 7-20.

VON RAD, U., EXON. N.F. \& HAQ, B.U. 1992. Rift-to-drift history of the Wombal Plateau, Northwest Australia: Triassic to Tertiary Leg 122 results. $m$ : voN RaD, U., HAQ, B.U. ET al. (eds) Proceedings of the Ocean Drilling Program, Scientific Results, 122. Occan Drilling Program, College Station. TX, 765-800.

WAN, X. WANG, L. WANG, C. \& JANSA, L. 1998. Discovery and significance of Cretaceous fossils from the Xigaze foreare basin, Tibet. Joumal of Asian Earth Sciences, 16, 217-223.

Wang, X.B., BAO, P.S. Ding, W.M. \& WANG. F.G. 1987. Tectonic evolution of the lithosphere of the Himalayas: Xizang (Tibet) ophiolite. In: Cindsst: Academy ol: Grological Soninces, (cd.) People's Republic of China Minisuy of Geology and Mineral Resources Geological Memoirs Series 3.8 $1-336$.

WestrRook. G.K 1982. The Barbados Ridge Complex: tectonics of a mature forcarc system, $m$. LrgGeTt, J.K. (ed.) Trench-Forear: Geologv: Sedimentation and Tectonics of Modem and Ancient Active Plate Margins. Geological Socicty, London, Specia! Publications, 10, 275-290

WIIJMANN, J. \& DÜRR, S.B. 1995. First ammonites from the Mid to Upper Cretaccous Xigaze Group, South Tibet, and their significance. Newsletters on Stratigraphy, 32(1), 17-26.

Wu, H.R. 1993. Upper Jurassic and Lower Cretaceous radiolarians of Xialu chert Yarlung Zangbo ophiolite belt, southern Tibet. $/ n$ : BLUirord, J.R. \& MurcueY, B.L. (eds) Radiolarid of Giant and Subgiant Fields of Asia, Nazarow Memorial Volume. Micropaleontology Special Paper, 6, I15 136.

XU, R.H., SChasRir. U. \& Ali.j;irl:, C.J. 1985. Magmatism and metamorphism in the Lhasa Block (Tibet): a geochronological study, Journal of Geologry, 93, $41-57$.

Yeir, K.Y. 1987. Taxonomic Sudies of Lower Jurassic Radiolaria fiom EastCentral Oregon. National Museum of Natura! Science, Taiwan, Special Publication, 2

YIN, A. \& HARrison, T.M. 2000. Geologic evolution of the Ilimalayan. Tibelan Orogen. Ammal Revicw of Earth and Planetary Sciences, 28, 211-280.

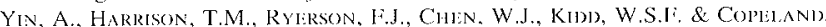
P. 1994. Tertiary structural cvolution of the Gangdese thrust system in southeastern Tibet. Journal of Geophwsical Research, 99, $18175 \cdot 18201$.

YiN, A. Harrison, T.M. \& Murpiry, M.A. aT AL. 1999. Tertiary deformation history of southeastern and southwestern Tibet during the Indo-Asian collision. Geological Society of America Bulletin, 111, 1644-1664.

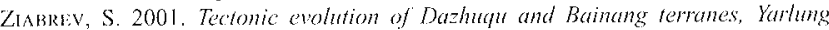
Zangho suture. Tibet as constrained by radiolarian biostratigraphy. PhI) thesis, University of Hong Kong.

Ziabrey, S.V., Atrchison, J.C., Ablzamiviter, A., Badengzhiu, Davis, A.M. \& Luo, H. 2003. Precise adiolarian age constraints on the timing of Dazhuqu terrane ophiolite greneration and sedimentation, Yarlung...Tsangpo suture zone, Tibet. Jominal of the Geological Society, London, 160, 591--600.

ZYABRs: S.V. 1996. Cretaceous radiolarian fauna from the Kielyovsky subterrane, the youngest accretionary complex of the Russian continental far east paleotectonic and paleogeographic implications. Island Aic, 5, 140-155.

Zyabrey, S.V., Attrhison, J.C., Badingzhu,, Davis, A.M., Luo, H. \& Mat.pas, J. 1999. Radiolarian biostratigraphy of supra-ophiolite sequences in the Xigaze area, Yarlung. Tsangpo suture, Southem Tibet (prcliminary report). Radiolaria, 17, 13-19. 